\title{
Impact of elevated carbon dioxide and temperature on strawberry polyphenols
}

Himali N. Balasooriya $^{{ }^{*}}$, Kithsiri B. Dassanayake ${ }^{1,2}$, Saman Seneweera ${ }^{1,3}$, Said Ajlouni ${ }^{{ }^{*}}$

1. School of Agriculture and Food, Faculty of Veterinary and Agricultural Sciences, The University of Melbourne, Parkville, VIC 3010 Australia.

2. Department of Infrastructure Engineering, Faculty of Engineering, The University of Melbourne, Parkville, VIC 3010 Australia.

3. National Institute of Fundamental Studies, Hantana Road, Kandy, Sri Lanka.

*Corresponding author; Himali N. Balasooriya - phone: +61420620730;

e-mail: hbalasooriya@student.unimelb.edu.au

This is the author manuscript accepted for publication and has undergone full peer review but has not been through the copyediting, typesetting, pagination and proofreading process, which may lead to differences between this version and the Version of Record. Please cite this article as doi: $10.1002 /$ jsfa.9706

This article is protected by copyright. All rights reserved. 


\section{Abstract}

Background: Strawberry cultivars ‘Albion' and 'San Andreas' were grown under various combinations of day temperature $\left(25\right.$ and $\left.30{ }^{\circ} \mathrm{C}\right)$ and carbon dioxide $\left[\mathrm{CO}_{2}\right](400,650$ and $950 \mu \mathrm{moL} / \mathrm{moL})$ conditions. The influence of different growth combinations on polyphenol, flavonoid, anthocyanin, antioxidant and individual phenolic compound contents of fresh strawberry fruits were studied. The contents of individual phenolic compounds of fresh strawberry fruits were quantified by using HPLC-UV system.

Results: Elevated $\left[\mathrm{CO}_{2}\right]$ and higher temperature caused significant increases in total polyphenol, flavonoid, anthocyanin and antioxidants in both strawberry cultivars when compared with plants grown under ambient growth conditions. Results of HPLC-UV analysis also revealed that individual phenolic compounds of fruits were also increased by increased $\left[\mathrm{CO}_{2}\right]$ and temperature. However, the responses were significantly altered by the interaction of elevated $\left[\mathrm{CO}_{2}\right]$ and higher temperature. In addition, the individual and interaction effects of $\left[\mathrm{CO}_{2}\right]$ and temperature were significantly cultivar dependent. The greatest amounts of flavonoid $(482 \pm 68 \mathrm{mg} / \mathrm{kg} \mathrm{FW})$ and antioxidant $(19.0 \pm 2.1 \mu \mathrm{moL} / \mathrm{g} \mathrm{FW})$ were detected in 'Albion' grown under $30{ }^{\circ} \mathrm{C}$ and $950 \mu \mathrm{moL} / \mathrm{moL}$, and total polyphenol $(3350 \pm 104 \mathrm{mg}$ GAE/kg FW) and anthocyanin $(332 \pm 16 \mathrm{mg} / \mathrm{kg} \mathrm{FW})$ in 'San Andreas' grown at $25{ }^{\circ} \mathrm{C}$ and 950 $\mu \mathrm{moL} / \mathrm{moL}$.

Conclusion: Strawberry fruits were rich with polyphenols and antioxidants when they were grown under elevated $\left[\mathrm{CO}_{2}\right]$, higher temperature and their interactions. The increase contents of polyphenols and antioxidants of strawberry fruits will be highly beneficial to human health.

\section{Keywords}

Carbon dioxide, HPLC, polyphenol, strawberry, temperature 


\section{Introduction}

Horticulture plants are used as the one of the main sources of food, fiber, biofuel, medicine and other products to sustain and enhance human life ${ }^{1-3}$. Strawberry (Fragaria ananassa Duch.) continues to acquire higher consumer demand globally due to its excellent nutrition profile including minerals, vitamin $\mathrm{C}$, folates and polyphenols ${ }^{4}$. Additionally, among fruits, strawberry has been consistently appreciated for its health benefits and high dietary fibre content. Phytochemicals in strawberry display an immense biological potential in humans by providing protective and preventing effects against most diseases ${ }^{4-8}$. Ascorbic acid, ellagitannins and polyphenols are the major antioxidant compounds in strawberry which can prevent oxidative stresses and related diseases ${ }^{8}$. Moreover, in addition to the antioxidant property, strawberry polyphenols possess a great interest among other dietary phytochemicals showing, anti-inflammatory, antimicrobial, antiallergy, and antihypertensive properties ${ }^{6}$. More than 40 different compounds of polyphenols have been identified in strawberries ${ }^{9}$ having diverse structure and function.

Flavonoids, tannins, phenolic acids, stilbenes and lignans are the major subgroups of polyphenols with the flavonoids being most abundant subgroup in plants ${ }^{10}$. Anthocyanins are quantitatively the most important subclass within flavonoids. They are the naturally occurring water soluble pigments which give strawberry its unique bright red colour, a critical factor in assessing the visual fruit quality of strawberries. The variability of anthocyanins is noteworthy, with more than 25 different anthocyanin compounds discovered in different strawberry cultivars ${ }^{11}$. Pelargonidin and cyanidin derivatives are the main categories in this group and while pelargonidin-3-glucoside (Pel-3-Glu) is the most dominant anthocyanin in strawberry. Cyanidin-3-glucoside (Cy-3-Glu) and pelargonidin-3-rutinoside (Pel-3-Rut) are the other commonly found anthocyanins in smaller amounts compared to Pel-3-Glu. Further, 
quercetin and kaempferol derivatives which belong to the subclass of flavonols in flavonoids, also function as co-pigments contributing to unique colour of strawberry fruits. Bioavailability, absorption and bioactivity of these compounds in humans are well-known to be relatively high ${ }^{4}$ despite the fact that they are present in strawberry at very low concentrations in comparison to pelargonidin and cyanidin derivatives.

Additionally, a range of other phenolic compounds such as phenolic acids (hydroxycinnamic acids, $p$ coumaroyl, ferulic acid derivatives), stilbenes (resveratrol) and coumarins ( $p$-coumaric acid) which are beneficial to human nutrition and health, have also been identified in strawberry fruits ${ }^{9,11-13}$. However, the strawberry polyphenol profile can widely vary qualitatively and quantitatively as affected by diverse factors, including genotype, environmental factors and their interactions ${ }^{14-21}$.

Genetic make-up of strawberries is the most critical contributory factor in the variability of nutritional quality of fruits in terms of total polyphenol content (TPC), total antioxidant content (TAC) and level of individual polyphenol; however, growing conditions or environmental factors also play a significant role in determining the nutritional value of strawberries ${ }^{14,16,18}$. Both genotype and environmental factors have been reported to significantly influence the chemical composition of strawberry ${ }^{12,14,22-25}$. In general, a range of abiotic (environmental factors including, climate, soil, water stress) and biotic (plant pest and diseases) factors are known to alter strawberry quality and antioxidant profile. However, due to the anticipated climate changes, environmental factors such as, air temperature and $\mathrm{CO}_{2}$ concentration $\left[\mathrm{CO}_{2}\right]$ are important as they are detrimental to the quality and nutritional value of strawberry. Atmospheric $\left[\mathrm{CO}_{2}\right]$ may increase from the current levels of $390 \mu \mathrm{moL} / \mathrm{moL}$ to around $1000 \mu \mathrm{moL} / \mathrm{moL}$ and temperature by 2.5 to $7.8^{\circ} \mathrm{C}$ at the end of this century ${ }^{26-29}$. These ongoing increases are predicted to cause significant changes in the quantity and quality of agricultural produce ${ }^{29}$. Furthermore, climate 
change could alter the water availability for crop production and increase the risks of drought and diseases, hence reduce food production and quality ${ }^{30,31}$. Therefore, these factors, independently or interactively are expected to cause a substantial influence on strawberry phytochemicals.

Among the abiotic factors, growing temperature significantly influences nutritional quality of strawberries ${ }^{21,32}$. For example, Wang and Zheng $^{21}$ demonstrated that increased polyphenol contents and high antioxidant capacity occur with increased day/night growing temperature. Further, Palmieri et al. ${ }^{17}$ reported enhanced concentrations of flavonols and ellagitannins in strawberries when the plants were subjected to higher temperature, ultraviolet irradiation and longer sunshine duration. Higher levels of anthocyanins and phenolic compounds were also reported when strawberries were grown under elevated $\left[\mathrm{CO}_{2}\right]\left(\mathrm{e}\left[\mathrm{CO}_{2}\right]\right)^{33}$. For example, resveratrol is an important polyphenol which provides several health benefits, was found in higher contents in strawberries grown either at high temperature or e[CO $\left.\mathrm{CO}_{2}\right]$ ${ }^{34}$. Sun et al. $^{24}$, on the other hand reported reductions in antioxidant activity and antioxidant compounds occurred in strawberries grown under e $\left[\mathrm{CO}_{2}\right]$.

In general, most studies in the past evaluated the effects of temperature and $\left[\mathrm{CO}_{2}\right]$ on the nutritional quality of strawberries separately. However, an understanding of the interactive effects of these two environmental factors (high temperature and $\left[\mathrm{CO}_{2}\right]$ ) on phytochemicals is limited in literature ${ }^{35}$. Thus, it is critical to investigate the interactive effects of $\mathrm{e}\left[\mathrm{CO}_{2}\right]$ and temperature on the nutritional quality, more importantly the antioxidant contents, especially polyphenols in strawberries.

Polyphenol profile of strawberry shows highly diverse composition and La Barbera et al. ${ }^{13}$ have confirmed or tentatively identified over 130 different individual compounds. The diversity of these compounds must be taken into consideration in fruit nutrition since the biological and pharmacological activities are specific to their chemical structure ${ }^{7}$. Therefore, analysing the amounts of individual 
compounds is important to evaluate the effects of genetic or environmental factors on the nutritional profile of fruits. Previous studies have mostly focused on total polyphenols as a group or a specific subgroup i.e. anthocyanins. However, a broad spectrum of polyphenol compounds would be available in different quantities in strawberries and will be affected in varying degrees by environmental factors. The study examined the effect of e $\left[\mathrm{CO}_{2}\right]$ and high temperature and their interactions on various polyphenols in two different strawberry cultivars.

\section{Materials and Methods}

\subsection{Chemicals}

HPLC gradient grade methanol, acetonitrile and formic acid were obtained from Thermo Fisher Scientific, Melbourne, Victoria, Australia. Hydrochloric acid, ethanol, Folin-Ciocalteu's reagent (FCR), Gallic acid, Sodium carbonate, 2, 2,-AzinoBis [3-ethylbenzo] Thiazoline-6-Sulfonic acid (ABTS), potassium persulfate, Trolox solution (6-hydroxy-2,5,7,8-tetramethylchroman-2-carboxylic acid), potassium chloride, sodium acetate, potassium persulfate, and formic acid were purchased from SigmaAldrich Co, NSW, Australia. For laboratory analysis, polyphenol extractions and HPLC mobile phase, ultrapure water (Milli- $\mathrm{Q}^{\circledR}$ water) was used. Milli-Q ${ }^{\circledR}$ water was generated from a Millipore Milli-Q

Ultrapure Water Purification System (ZMQP60001), Massachusetts, United States. HPLC grade (e99.0\%) reference standards; catechin, callistephin chloride, cyanidin chloride, $p$-coumaric, 6-O-pCoumaroyl-1,2-digalloylglucose, trans ferulic acid and resveratrol were also purchased from SigmaAldrich Co, NSW, Australia. HPLC grade reference standards; pelargonidin-3-rutinoside chloride, kaempferol-3-O-glucoside, kaempferol-3-glucurnoride, quercertin-3,4-di-glucoside and quercertin-3-Oglucuronide were purchased from Extrasynthase, Genay Cedex, France.

\subsection{Strawberry Fruits}


Strawberries used in this study were produced from strawberry plants grown in controlled environment (CE) chambers (Model: TPG-2400-TH-CO $\mathrm{CO}_{2}$ Thermoline Scientific Equipment Pty. Ltd., Wetherill Park, NSW, Australia) at the Parkville Campus of The University of Melbourne, Australia as described by Balasooriya et al. ${ }^{36}$. Briefly, two different day neutral strawberry cultivars, "Albion' and "San Andreas (SA)" were grown under different $\left[\mathrm{CO}_{2}\right]$ and temperature combinations inside automated $\mathrm{CE}$ chambers. The six different treatment combinations were $400 \mu \mathrm{moL} / \mathrm{moL} \times 25{ }^{\circ} \mathrm{C}, 400 \mu \mathrm{moL} / \mathrm{moL} \times 30{ }^{\circ} \mathrm{C}, 650$ $\mu \mathrm{moL} / \mathrm{moL} \times 25{ }^{\circ} \mathrm{C}, 650 \mu \mathrm{moL} / \mathrm{moL} \times 30{ }^{\circ} \mathrm{C}, 950 \mu \mathrm{moL} / \mathrm{moL} \times 25{ }^{\circ} \mathrm{C}$ and $950 \mu \mathrm{moL} / \mathrm{moL} \times 30{ }^{\circ} \mathrm{C}$. Each experiment had four replicates and there were three plants per replicate. The treatments were applied during plant growth and development until fruit harvesting. Finally, healthy fruits (including all primary and secondary fruits) with $90 \%$ red colour were harvested separately from each chamber for each cultivar and for each replicate.

The antioxidant and polyphenol properties of strawberries were analysed in fresh strawberry fruits. Fruits for fresh analysis were stored in a cold room at $4{ }^{\circ} \mathrm{C}$ until use.

\subsection{Extraction of strawberry Polyphenols}

Polyphenol compounds in strawberry fruits were extracted using $70 \%$ methanol and $0.18 \mathrm{~N} \mathrm{HCl}$ following the method described by Tow et al. ${ }^{37}$ with some modifications. Triplicate samples ( $5 \mathrm{~g}$ each) of fresh strawberry was homogenised with $70 \%$ methanol $(15 \mathrm{~mL})$ and $0.18 \mathrm{~N} \mathrm{HCl}(5 \mathrm{~mL})$ in $50 \mathrm{~mL}$ polyethylene tube (Ultra Turrax homogenizer, Janke and Kunnel, IKA-Labortechnik Ultra-Turrax T25). The homogenate was centrifuged at 8422g (Centrifuge, Thermoline, Scientific Equipment Pvt Ltd) for 15 minutes at room temperature and the resultant supernatant was collected quantitatively. The residue was washed with an additional $5 \mathrm{ml}$ of methanol and the supernatants were combined. Methanol was evaporated from the collected supernatant under vacuum in a rotary evaporator at $60{ }^{\circ} \mathrm{C}$ with $8 \mathrm{rpm}$. 
The final extract was re-dissolved in Milli-Q water and the final volume was adjusted to $25 \mathrm{~mL}$ using a volumetric flask. This final polyphenol extract was then used for analysing the total antioxidants, polyphenols, flavonoid and anthocyanin contents in strawberries. An aliquot $(2 \mathrm{~mL})$ of the extract was filtered through $0.45 \mu \mathrm{m}$ membrane when used for the analysis of individual polyphenol compounds using HPLC.

\subsection{Total Polyphenol Content (TPC)}

The TPC was measured following the method described by Tow et al. ${ }^{37}$. In this method, a mixture of 20 $\mu \mathrm{L}$ of polyphenol sample extract, $100 \mu \mathrm{L}$ of $0.2 \mathrm{~N}$ Folin-Ciocalteu's reagent (FCR), $200 \mu \mathrm{L}$ of Milli-Q water and $80 \mu \mathrm{L}$ of sodium carbonate $(7.5 \% \mathrm{w} / \mathrm{v})$ was incubated at room temperature for one hour in a 96 well microplate. Absorption was then measured at $756 \mathrm{~nm}$ using a micro plate reader (Multiskan GO, Thermo Scientific, Australia) and the total polyphenol content was expressed as milligrams of Gallic acid equivalent (GAE) per kilogram of fresh strawberry sample $(\mathrm{mg} / \mathrm{kg} \mathrm{FW})$. The same procedures were repeated with the solvent blank and the gallic acid standards.

\subsection{Total Antioxidant Capacity (TAC)}

The TAC in strawberry samples was analysed using ABTS assay by Re et al. ${ }^{38}$ with slight modifications. The $\mathrm{ABTS}^{\circ+}$ radicals solution was prepared by reacting the stock solution of ABTS (7 $\mathrm{mM}$ ) with $2.45 \mathrm{mM}$ potassium per sulfate at the same ratio. The mixture was incubated overnight in the dark to generate the green ABTS - organic free radicals. It was then diluted with methanol to an absorbance of 0.7 at $»=734 \mathrm{~nm}$. Sample extract or standard Trolox solution $(25 \mu \mathrm{L})$ was mixed with ABTS solution $(250 \mu \mathrm{L})$ directly in a 96 wells microplate and the absorbance was read at $734 \mathrm{~nm}$ after 6 mins. TAC was reported as $\mu \mathrm{moL}$ Trolox equivalents per gram of strawberry fresh weight $(\mu \mathrm{moL} / \mathrm{g}$ FW). 


\subsection{Total Monomeric Anthocyanin Content (TMAC)}

The TMAC of strawberries was determined using the $\mathrm{pH}$ differential method as described by Giusti and Wrolstad ${ }^{39}$. This method is based on the significant reversible changes in absorption of the anthocyanin pigments when the $\mathrm{pH}$ changes between 1.0 (highest absorption) and 4.5 (lowest $=$ colourless hemiketal). The strawberry samples were appropriately diluted in $0.025 \mathrm{M}$ potassium chloride ( $\mathrm{pH} 1.0)$ and $0.4 \mathrm{M}$ sodium acetate $(\mathrm{pH} 4.5)$. The mixtures were kept for 15 mins at room temperature before the absorptions were measured at 496 and $700 \mathrm{~nm}$ using the microplate reader. TMAC was calculated using molar absorptivity of $27300 \mathrm{~L} \mathrm{~cm} / \mathrm{moL}$ and molecular weight of $433.2 \mathrm{~g} / \mathrm{mol}$ for the anthocyanin Pel-3glu and expressed as $\mathrm{mg} / \mathrm{kg} \mathrm{FW}$.

\subsection{Total Flavonoid Content (TFC)}

A slightly modified colorimetric aluminium chloride method ${ }^{40}$ was used in the determination of TFC of samples. In a microplate well, $125 \mu \mathrm{L}$ of strawberry extract or solvent blank or quercetin standard was mixed with $25 \mu \mathrm{L}$ of $1 \mathrm{M}$ sodium acetate, $25 \mu \mathrm{L}$ of $10 \%$ aluminium chloride, and $175 \mu \mathrm{L}$ of Milli-Q water. The mixtures in the microplate were then left at room temperature for $1 \mathrm{~h}$ before measuring the absorbance at $415 \mathrm{~nm}$ using a micro plate reader. TFC was calculated using quercetin as a standard and expressed as mg of quercetin equivalents per kilogram of strawberry fresh weight $(\mathrm{mg} / \mathrm{kg} \mathrm{FW})$.

\subsection{HPLC-UV analysis for Identification and Quantification of Individual Polyphenols}

Separation of polyphenols was performed using a Gemini C18 silica $250 \times 4.6 \mathrm{~mm}, 5 \mu \mathrm{m}$ column (Phenominex Inc., Lane Cove West, NSW, Australia) connected to a HPLC system equipped with Water 2690 Alliance Separation Module (Waters, Rydalmere NSW, Australia) and coupled with a Waters 2998 Photodiode Array (PDA) Detector. HPLC analysis was performed using a previous method by Kosar et 
al. ${ }^{16}$ with slight modifications. The mobile phase was acidified with $0.2 \%(\mathrm{v} / \mathrm{v})$ formic acid in Milli-Q water, (A) and acetonitrile (B). The gradient was 5\% B for $1 \mathrm{~min}, 10 \% \mathrm{~B}$ at $10 \mathrm{~min}, 13 \% \mathrm{~B}$ at $15 \mathrm{~min}$, $20 \% \mathrm{~B}$ at $20 \mathrm{~min}, 30 \% \mathrm{~B}$ at $25 \mathrm{~min}, 100 \% \mathrm{~B}$ at $35 \mathrm{~min}$, and returned to $5 \% \mathrm{~B}$ at $40 \mathrm{~min}$. The injection volume was $20 \mu \mathrm{L}$ and the flow rate was maintained at $1 \mathrm{~mL} / \mathrm{min}$. Separation and quantification of polyphenols were performed at room temperature $\left(25^{\circ} \mathrm{C}\right)$. Identification of individual polyphenol peaks was based on both internal and external standards ${ }^{41}$. Identified peaks in strawberry extracts were quantified based on peak area and mass of the external calibration standard that generated the corresponding curve to the peak. During the quantification, average peak area was calculated as the average of two targeted peaks from duplicated HPLC injections. Different polyphenol compounds were detected and quantified at optimum and different wavelengths as required. These included, Pel-3-Glu, Pel-3-Rut and Cyanidin at $510 \mathrm{~nm}$; Kaempferol-3-Glucoside and Kaempferol-3-Glucurnoride at $360 \mathrm{~nm}$; Resveratrol at $320 \mathrm{~nm}$; and Catechin, Ferulic acid, Quercertin-3,4-di Glucoside, Quercertin-3-OGlucuronide, $p$-coumaric and p-Coumaroyl at $280 \mathrm{~nm}$. Results were expressed as milligram or microgram per kilogram of strawberry fresh weight $(\mathrm{mg} \text { or } \mu \mathrm{g} / \mathrm{kg} \mathrm{FW})^{12}$.

\subsection{Statistical Analysis}

Each laboratory experiment was performed in duplicate ( 2 trial) and each sample was triplicated in each trial. The results were presented as mean \pm standard deviation (SD). Data were statistically analysed using Minitab ${ }^{\circledR} 17$ Statistical Software following Analysis of Variance procedure with a General Linear Model (Minitab 17 Statistical Software (2010). The differences between the means were determined using Tukey's multiple comparison method at 95\% confidence level.

\section{Results and Discussion}




\subsection{Effect of high temperature and $\mathrm{e}\left[\mathrm{CO}_{2}\right]$ on total polyphenols, flavonoid, anthocyanin and antioxidant contents in fresh strawberry}

In general, increase in $\left[\mathrm{CO}_{2}\right]$ from 400 to $950 \mu \mathrm{moL} / \mathrm{moL}$, tended to increase TPC, TFC, TMAC and TAC of strawberry fruits significantly $(\mathrm{P}<0.05)$ across cultivars. Increase temperature in $5{ }^{\circ} \mathrm{C}$ significantly enhanced the TPC, TFC, TMAC and TAC of strawberries irrespective to the cultivar. However, strawberry fruits in cultivar 'Albion' contained significantly higher TAC than 'SA' grown under higher temperature $\left(30^{\circ} \mathrm{C}\right)$. As a whole, considering the effect of strawberry cultivar, fruits of 'San Andreas' had remarkably higher contents of total polyphenols and anthocyanin however, TAC of fruits was significantly higher in cultivar 'Albion'. The interaction of $\left[\mathrm{CO}_{2}\right]$ and temperature had significant impacts on TPC, TFC, TMAC and TAC of strawberries and the responses were cultivar dependant.

The effects of temperature, $\left[\mathrm{CO}_{2}\right]$ and their interactions on TPC of fruits in strawberry cultivars 'Albion' and 'SA' are shown in Figure I. In general, TPC of strawberry ranged from $970 \pm 74$ to $2856 \pm 134 \mathrm{mg}$ GAE/kg FW for the cultivar 'Albion', and from $904 \pm 87$ to $3350 \pm 104 \mathrm{mg}$ GAE/kg FW for the cultivar 'SA'. Although higher temperature $\left(30^{\circ} \mathrm{C}\right)$ had significant positive impacts on TPC of strawberry grown at ambient $(400 \mu \mathrm{moL} / \mathrm{moL})$ and moderately high $(650 \mu \mathrm{moL} / \mathrm{moL})\left[\mathrm{CO}_{2}\right]$, the effects turned negative at very high $\left[\mathrm{CO}_{2}\right]$, indicating strong temperature and $\left[\mathrm{CO}_{2}\right]$ interactions on TPC. The highest TPC were detected at the maximum level of $\left[\mathrm{CO}_{2}\right]$ and $25{ }^{\circ} \mathrm{C}$ temperature in both 'Albion' and 'SA' while, the lowest TPC were observed under $400 \mu \mathrm{moL} / \mathrm{moL}$ and $25^{\circ} \mathrm{C}$ for both strawberry cultivars (Figure I).

Consequently, it could be concluded that despite the increases in temperature, elevated $\left[\mathrm{CO}_{2}\right]$ positively affected on TPC in fruits of both cultivars. Increase in temperature by $5{ }^{\circ} \mathrm{C}$ than $25{ }^{\circ} \mathrm{C}$ under 400 $\mu \mathrm{moL} / \mathrm{moL}\left[\mathrm{CO}_{2}\right]$ enhanced fruit polyphenol contents by $68 \%$ and $98 \%$ in 'Albion' and 'SA', 
respectively. At lower $\left[\mathrm{CO}_{2}\right] ; 400 \mu \mathrm{moL} / \mathrm{moL}$ and $650 \mu \mathrm{moL} / \mathrm{moL}$, increased temperature by $5{ }^{\circ} \mathrm{C}$ than $25^{\circ} \mathrm{C}$ increased the TPC of fruits but, it was opposite at $950 \mu \mathrm{moL} / \mathrm{moL}$ in both cultivars. However, both elevated temperature $\left(30{ }^{\circ} \mathrm{C}\right)$ and $\left[\mathrm{CO}_{2}\right]$ to $950 \mu \mathrm{mol} \mathrm{mol}{ }^{-1}$ increased polyphenols by $182 \%$ in 'Albion' and $206 \%$ in 'SA'.

The TFC of fruits in both strawberry cultivars under different temperature, $\left[\mathrm{CO}_{2}\right]$ and their interactions are shown in Figure II. The TFC of fruits ranged from $173 \pm 48$ to $482 \pm 68 \mathrm{mg} / \mathrm{kg}$ FW for the cultivar 'Albion' and from $155 \pm 30$ to $405 \pm 43 \mathrm{mg} / \mathrm{kg} \mathrm{FW}$ for the cultivar 'SA'. Increased temperature $\left(30{ }^{\circ} \mathrm{C}\right)$ under $400 \mu \mathrm{moL} / \mathrm{moL}\left[\mathrm{CO}_{2}\right]$ significantly enhanced the contents of strawberry flavonoids by $65 \%$ and $113 \%$ respectively in 'Albion and ' $\mathrm{SA}$ '. The interaction of $\mathrm{e}\left[\mathrm{CO}_{2}\right]$ and higher temperature also had significant impact on TFC of strawberry and varied across the cultivar. Interactively, $950 \mu \mathrm{mol} \mathrm{mol}^{-1}$ $\left[\mathrm{CO}_{2}\right]$ and $30{ }^{\circ} \mathrm{C}$ enhanced the TFC by $183 \%$ and $173 \%$ respectively in 'Albion' and 'SA'. The interaction effect of $\mathrm{e}\left[\mathrm{CO}_{2}\right]$ and temperature was stronger on TFC of fruits in cultivar 'SA' than 'Albion' (Figure II). Significantly lower contents of total flavonoid were reported at $400 \mu \mathrm{mol} \mathrm{mol}{ }^{-1}\left[\mathrm{CO}_{2}\right]$ and 25 ${ }^{\circ} \mathrm{C}$ in both cultivars.

Figure III illustrates the effects of temperature, $\left[\mathrm{CO}_{2}\right]$ and their interactions in growth environment on TMAC of strawberry fruits in cultivar 'Albion' and 'SA'. The TMAC ranged from $70 \pm 14$ to $285 \pm 14$ $\mathrm{mg} / \mathrm{kg} \mathrm{FW}$ in cultivar 'Albion' and from $67 \pm 15$ to $331 \pm 16 \mathrm{mg} / \mathrm{kg} \mathrm{FW}$ in 'SA'. Temperature increase in 5 ${ }^{\circ} \mathrm{C}$ under lower and moderately high $\left[\mathrm{CO}_{2}\right]$ affected positively on TMAC of fruits in cultivar 'SA' however, altered to a negative at $950 \mu \mathrm{moL} / \mathrm{moL}\left[\mathrm{CO}_{2}\right]$ showing a stronger interaction of $\left[\mathrm{CO}_{2}\right]$ and temperature. Although, higher temperature showed significantly positive impacts on TMAC of fruits in cultivar 'Albion' under 400 and $950 \mu \mathrm{moL} / \mathrm{moL}$, affected negatively at $650 \mu \mathrm{moL} / \mathrm{moL}$. The results also revealed a significant interaction effect of $\left[\mathrm{CO}_{2}\right]$, temperature and cultivar on the TMAC of strawberry 
fruits (Figure III). Moderately high $\left[\mathrm{CO}_{2}\right]$ and $30{ }^{\circ} \mathrm{C}$ had significantly positive impact on TMAC in cultivar 'SA' however, it was totally opposite for cultivar 'Albion'. Such variation in the responces of the tested culitvars to elevated $\left[\mathrm{CO}_{2}\right]$ and temperature could be attributed to the influence of each cultivar genotype on strawberry polyphenols. Increased temperature from 25 to $30{ }^{\circ} \mathrm{C}$ at $400 \mu \mathrm{moL} / \mathrm{moL}$ enhanced strawberry anthocyanins only by $80 \%$ and $70 \%$ in 'Albion' and 'SA', respectively. The increase in TMAC of strawberries grown under $950 \mu \mathrm{moL} / \mathrm{moL}\left[\mathrm{CO}_{2}\right]$ and $30{ }^{\circ} \mathrm{C}$ temperature was approximately $300 \%$ to $350 \%$ in comparison to the fruits grown under ambient growth conditions which had the lowest TMAC.

Figure IV shows the effects of $\left[\mathrm{CO}_{2}\right]$, temperature and their interactions on the TAC of strawberry fruits. The interaction effect of $\left[\mathrm{CO}_{2}\right]$ and temperature on TAC of strawberry was significant and cultivar dependent (Figure IV). Increased temperature to $30{ }^{\circ} \mathrm{C}$ positively affected on the content of strawberry antioxidants under all $\left[\mathrm{CO}_{2}\right]$ in cultivar 'Albion' however, negatively affected on TAC of fruit in cultivar 'SA' under moderate and highest $\left[\mathrm{CO}_{2}\right]$. Increased temperature by $5{ }^{\circ} \mathrm{C}$ than $25^{\circ} \mathrm{C}$ under ambient $\left[\mathrm{CO}_{2}\right]$ enhanced TAC of strawberry fruits by $46 \%$ and $80 \%$ respectively in cultivar 'Albion' and 'SA'. However, the highest e[CO $\left[\mathrm{CO}_{2}\right]$ and higher temperature increased TAC by $179 \%$ and $110 \%$, respectively in 'Albion' and 'SA'. The results explained a stronger interaction of $\left[\mathrm{CO}_{2}\right]$, temperature and cultivar on TAC of strawberries. Cultivar 'Albion' had the maximum Trolox equivalents TAC of 19.0 $\pm 2.1 \mu \mathrm{moL} / \mathrm{g}$ FW under $950 \mu \mathrm{moL} / \mathrm{moL}$ and $30{ }^{\circ} \mathrm{C}$ and ' $\mathrm{SA}$ ' contained the maximum of $12.6 \pm 1.3 \mu \mathrm{moL} / \mathrm{g}$ FW under $950 \mu \mathrm{moL} / \mathrm{moL}$ and $25^{\circ} \mathrm{C}$. Therefore, strawberry would contain greater contents of fruit antioxidants under elevated $\left[\mathrm{CO}_{2}\right]$ and high temperature. These findings were in agreement with results reported in section 3.1, regarding the effect of high temperature and elevated $\mathrm{CO}_{2}$ on total polyphenols contents, and the conclusion of Wang and Lin ${ }^{42}$. Additionally, it has been reported that total antioxidants of fruits 
would increase significantly in the presence of higher contents of polyphenols ${ }^{43}$, flavonoids and $\operatorname{anthocyanins}^{44}$.

The correlations between TAC and TPC, TFC and TMAC were summarised in Table I. The correlation values between the TAC and TPC, TFC and TMAC were $\mathrm{r}=0.94, p \mathrm{~d} 0.001, \mathrm{r}=0.79, p \mathrm{~d} 0.05$ and $\mathrm{r}=$ 0.73, $p \mathrm{~d}$ 0.05, respectively. Similarly, the results also revealed that TPC significantly correlated with both TFC and TMAC $(r=0.92, p \mathrm{~d}$ 0.001) of strawberries. Further, TFC positively correlated with TMAC $(\mathrm{r}=0.85, p \mathrm{~d} 0.001)$ in fresh strawberries.

The positive correlation between increment in antioxidant, phenolic, anthocyanin, and flavonoid compounds was also reported by Wang et al. ${ }^{33}$. It is evident that flavonoids may increase in plants as a part of general stress response and provide beneficial antioxidant properties ${ }^{45}$. These antioxidant compounds are produced in plants help to reduce oxidative stresses caused by free radicals ${ }^{46}$. The hydroxyl groups attached to the aromatic rings are responsible for the free radical scavenging properties of phenolic compounds. Besides the direct health benefits of polyphenols as antioxidants, strawberry polyphenols indirectly play a fundamental role against chronic metabolic disorders and cancers ${ }^{7}$. The same authors explained that strawberry polyphenols may be involved with cellular signalling, control the gene transcription and expression in cellular metabolism and survival in preventing chronic disorders and cancers.

Previous studies have reported significantly higher contents of polyphenols, flavonoids, anthocyanins and antioxidants under increased growth temperatures ${ }^{21}$ or e $\left[\mathrm{CO}_{2}\right]^{33}$. In this study, e $\left[\mathrm{CO}_{2}\right]$, increased temperature and their interactions enhanced the levels of polyphenols, flavonoids, anthocyanins and antioxidants in strawberry however, these responses were significantly varied across the cultivars. Highest TPC and TMAC were detected in cultivar 'SA'. However, TFC and TAC were significantly 
$(\mathrm{P}<0.05)$ higher in cultivar 'Albion'. A previous study by Palmieri et al. ${ }^{17}$ demonstrated the effect of genotype and environmental conditions on nutrient contents in nine strawberry cultivars. According to those results, amongst the nine cultivars, 'Albion' was the most sensitive cultivar, which responded to the different environmental conditions. Palmieri et al. ${ }^{17}$ attributed the higher contents of plant secondary products under different growth conditions to the acclimatization imposed by environmental stresses.

The same authors concluded that genotype was more influential on some strawberry cultivars over all the other parameters. A study by Ariza et al. ${ }^{47}$ showed that genotype has a strong influence on strawberry phenolic and anthocyanin contents. Similar to the genotype effect, the current study revealed that $\mathrm{e}\left[\mathrm{CO}_{2}\right]$ and/or higher temperature could significantly $(\mathrm{P}<0.05)$ enhance the polyphenol and antioxidant contents of strawberry fruits. Since polyphenols, flavonoids, anthocyanins, and antioxidants are considered as important fruit bioactive compounds, increasing the contents of such fruit nutrients with $\mathrm{e}\left[\mathrm{CO}_{2}\right]$, higher temperature and their interactions would improve strawberry functional properties. Consequently, strawberry grown under higher temperature $\left(30{ }^{\circ} \mathrm{C}\right)$ and $\mathrm{e}\left[\mathrm{CO}_{2}\right](650$ and 950 $\mu \mathrm{moL} / \mathrm{moL})$, could support a better human health.

\subsection{Identification and quantitation of individual polyphenols in strawberry gown under high temperature and $\mathrm{e}\left[\mathrm{CO}_{2}\right]$}

The main polyphenols that have been reported in strawberry belong to chemical classes namely; flavonoids (anthocyanins, flavanols, flavonols), phenolic acids, lignans, stilbens, tannins and coumarins 48. In this investigation, tweleve different phenolic compounds were identified in strawberry cultivars 'Albion' and 'SA' using external and internal standards at different wavelength (Table II). HPLC chromatograms of polyphenol compounds in strawberries at different wavelengths are shown in Figure V. 
Peak 2 detected at $280 \mathrm{~nm}, 320 \mathrm{~nm}$ and $360 \mathrm{~nm}$ (Figure V) could not be identified with external or internal standards due to the inaccessibility of the reference standard. According to the literature ${ }^{11,49}$, this peak could be cyanidin-3-glucoside, and was reported to be constant in all strawberry varieties ${ }^{11}$. Most of the identified polyphenol compounds were quantified considering their peak areas at the maximum absorbance. Table III and IV show the concentrations of different polyphenol compounds of fresh fruits of strawberry cultivars 'Albion' and 'SA' and illustrate the effects of different $\left[\mathrm{CO}_{2}\right]$, temperature and their interactions on each compound.

\subsubsection{Effect of $\mathrm{e}\left[\mathrm{CO}_{2}\right]$ and high temperature on strawberry anthocyanins}

Anthocyanins have an utmost importance in strawberry polyphenol profile, specifically, the major group of pigments accounts for strawberry colour. Specially, the aglycones of pelargonidin and cyanidin are the predominantly found anthocyanins ${ }^{11}$ and are highly responsible for the red colour depending on cultivar $^{22}$. Pel-3-Glu revealed the highest contents followed by cyanidin and Pel-3-Rut in both 'Albion' and 'SA'. The impacts of $\left[\mathrm{CO}_{2}\right]$, temperature, and their interactions on different anthocyanins compounds of fruits in strawberry cultivars 'Albion' and 'San Andreas' are shown in Table III.

The Pel-3-Glu content ranged from $115 \pm 23$ to $273 \pm 30 \mathrm{mg} / \mathrm{kg}$ FW for cultivar 'Albion' and from $114 \pm 24$ to $348 \pm 33 \mathrm{mg} / \mathrm{kg} \mathrm{FW}$ for cultivar ' $\mathrm{SA}$ '. Elevated $\left[\mathrm{CO}_{2}\right]$ gradually increased the content of Pel-3-Glu in strawberry fruits in both cultivars. Elevated $\left[\mathrm{CO}_{2}\right]$ to $950 \mu \mathrm{moL} / \mathrm{moL}$ caused $137 \%$ and $205 \%$ increment in Pel-3-Glu content in 'Albion' and 'SA' respectively in comparison with the growth at $400 \mu \mathrm{moL} / \mathrm{moL}$ and $25{ }^{\circ} \mathrm{C}$. Higher temperature had positive impact on Pel-3-Glu only at $400 \mu \mathrm{moL} / \mathrm{moL}$ by increasing the contents of Pel-3-Glu by $15 \%$ and $51 \%$ in 'Albion' and 'SA' respectively. Under e[ $\left.\mathrm{CO}_{2}\right](650$ and $950 \mu \mathrm{moL} / \mathrm{moL}), 30{ }^{\circ} \mathrm{C}$ temperature had negative impact on Pel-3-Glu showing the significant interaction effect of $\left[\mathrm{CO}_{2}\right]$ and temperature. The interaction of elevated $\left[\mathrm{CO}_{2}\right](950 \mu \mathrm{moL} / \mathrm{moL})$ and 
higher temperature $\left(30^{\circ} \mathrm{C}\right)$ enhanced Pel-3-Glu contents by $90 \%$ and $103 \%$ in 'Albion' and 'SA' respectively, in comparison with plants grown under $400 \mu \mathrm{moL} / \mathrm{moL}$ and $25^{\circ} \mathrm{C}$. The maximum contents of Pel-3-Glu were detected under maximum e $\left[\mathrm{CO}_{2}\right]$ and $25{ }^{\circ} \mathrm{C}$ in both cultivars however, cultivar 'SA' contained significantly higher Pel-3-Glu contents than 'Albion'.

Elevated $\left[\mathrm{CO}_{2}\right]$ and higher temperature separately showed positive effects on Pel-3-Rut contents in both cultivars (Table III). Highest $\mathrm{e}\left[\mathrm{CO}_{2}\right]$ and higher temperature interactively enhanced the Pel-3-Rut contents of fruits from $18 \pm 3$ to $41 \pm 4 \mathrm{mg} / \mathrm{kg} \mathrm{FW}$ for cultivar 'Albion' and from $24 \pm 4$ to $58 \pm 6 \mathrm{mg} / \mathrm{kg} \mathrm{FW}$ for cultivar 'SA', respectively. The interaction effect of $\left[\mathrm{CO}_{2}\right]$ and temperature on Pel-3-Rut contents was significantly cultivar dependant. Higher temperature and $950 \mu \mathrm{mol} \mathrm{mol}{ }^{-1}\left[\mathrm{CO}_{2}\right]$ positively affected on Pel-3-Rut contents of strawberries in cultivar 'Albion' however, the effect turned negative in cultivar 'SA' (Table III). Under all growth combinations, 'SA' contained comparatively and significantly higher contents of Pel-3-Rut than 'Albion'.

Cyanidin contents of fruits in strawberry cultivars 'Albion' and 'SA' were increased by e[CO $\left.\mathrm{CO}_{2}\right]$ from 400 to $950 \mu \mathrm{moL} / \mathrm{moL}$ (Table III). However, the interaction of $\mathrm{e}\left[\mathrm{CO}_{2}\right]$ and temperature was stronger on cyanidin contents of strawberry than their individual impacts. Increased temperature by $5{ }^{\circ} \mathrm{C}$ than $25^{\circ} \mathrm{C}$ was positively affected on cyanidin contents of strawberry fruits in both cultivars only under 400 and $950 \mu \mathrm{moL} / \mathrm{moL}\left[\mathrm{CO}_{2}\right]$. Higher temperature had negative impacts on cyanidin contents under 650 $\mu \mathrm{moL} / \mathrm{moL}$ in both cultivars. Elevated $\left[\mathrm{CO}_{2}\right]$ of $950 \mu \mathrm{moL} / \mathrm{moL}$ and $30{ }^{\circ} \mathrm{C}$ increased the content of cyanidin from $27 \pm 4$ to $175 \pm 32 \mathrm{mg} / \mathrm{kg} \mathrm{FW}$ in cultivar 'Albion' and from $28 \pm 3$ to $150 \pm 22 \mathrm{mg} / \mathrm{kg} \mathrm{FW}$ in 'SA'. Elevated $\left[\mathrm{CO}_{2}\right]$ from 400 to $950 \mu \mathrm{moL} / \mathrm{moL}$ at $30{ }^{\circ} \mathrm{C}$ increased the cyanidin content by $600 \%$ and $435 \%$ in 'Albion' and 'SA', respectively. 
Both, Pel-3-Glu and Pel-3- Rut (pelargonidin derivatives) were detected in larger quantities in cultivar 'SA', while cyanidin was present in large quantities in cultivar 'Albion' when grown under highest $\mathrm{e}\left[\mathrm{CO}_{2}\right]$ and higher temperature $\left(950 \mu \mathrm{moL} / \mathrm{moL}\right.$ and $\left.30^{\circ} \mathrm{C}\right)$. These results were in agreement with those reported by Wang and Zheng ${ }^{21}$ and Wang et al. ${ }^{33}$.

\subsubsection{Effect of e[COO $\left.\mathrm{CO}_{2}\right]$ and high temperature on strawberry flavonols}

Flavonols compounds showed significant variations under increased $\left[\mathrm{CO}_{2}\right]$, temperature, and their combination (Table III). Flavonol contents were comparatively lower than the anthocyanins contents in strawberries. Quercetin glucoside (Q-3, 4-di-O-Glu) contents of fruits ranged from $10.1 \pm 1.0$ to $24.8 \pm 2.8$ $\mathrm{mg} / \mathrm{kg}$ of FW and $9.8 \pm 1.0$ to $25.1 \pm 3.0 \mathrm{mg} / \mathrm{kg} \mathrm{FW}$ in cultivars 'Albion' and 'SA', respectively (Table III). Elevated $\left[\mathrm{CO}_{2}\right]$ significantly increased the contents of Q-3, 4-di-O-Glu at $25{ }^{\circ} \mathrm{C}$ in both strawberry cultivars. Higher temperature individually enhanced the Q-3, 4-di-O-Glu contents of strawberries however, interactively with $950 \mu \mathrm{moL} / \mathrm{moL}$ affected negatively on Q-3, 4-di-O-Glu contents in both strawberry cultivars.

Kaempferol glucoside (K-3-Glu'side) and glucuronide (K-3-Glu'nide) were found in comparatively smaller quantities in strawberries compared to other flavonoids (Table III). K-3-Glu'side content varied from $596 \pm 81$ to $1648 \pm 121 \mu \mathrm{g} / \mathrm{kg} \mathrm{FW}$ and $603 \pm 85$ to $1849 \pm 33 \mu \mathrm{g} / \mathrm{kg} \mathrm{FW}$ in cultivar 'Albion' and 'SA', respectively. Elevated $\left[\mathrm{CO}_{2}\right]$, temperature and their interactions significantly increased the kaempferol amounts in strawberries however, the amounts were varied among cultivars. Unsimilar to anthocyanins, which showed the greatest increment at $30{ }^{\circ} \mathrm{C}$ and $950 \mu \mathrm{moL} / \mathrm{moL} \mathrm{CO}_{2}$, the maximum amounts of $\mathrm{K}-3$ Glu'side were detected under $950 \mu \mathrm{moL} / \mathrm{moL}$ and $25{ }^{\circ} \mathrm{C}$ growth conditions in both cultivars. K-3Glu'nide content ranged from $512 \pm 81$ to $1767 \pm 121 \mu \mathrm{g} / \mathrm{kg} \mathrm{FW}$ and from $591 \pm 85$ to $1527 \pm 28 \mu \mathrm{g} / \mathrm{kg} \mathrm{FW}$ in 'Albion' and 'SA', respectively. The lowest amounts were detected under $400 \mu \mathrm{moL} / \mathrm{moL}$ and $25^{\circ} \mathrm{C}$ 
and the highest contents under highest $\mathrm{e}\left[\mathrm{CO}_{2}\right]$ and higher temperature. Similar to the results for anthocyanins, most flavonols contents revealed the greatest amounts under extreme growth condition of $30{ }^{\circ} \mathrm{C}$ and $950 \mu \mathrm{moL} / \mathrm{moL}$. These findings are in agreement with those reported in the literature ${ }^{21,33}$. For example, Wang et al. ${ }^{33}$ reported higher quercetin glucoside, quercetin glucuronide and kaempferol glucoside concentrations in strawberry fruits under enriched $(600 \mu \mathrm{moL} / \mathrm{moL}$ than ambient $)\left[\mathrm{CO}_{2}\right]$ condition. These flavonoids contain hydroxyl or methoxy groups which to contribute their biological and antioxidant properties. Therefore, increased amounts of these flavonoids play pivotal roles in preventing oxidative stresses ${ }^{50}$.

\subsubsection{Effect of e[COO $\left.\mathrm{CO}_{2}\right]$ and high temperature on other phenolic compounds}

In addition to flavonols that were discussed before, catechin, ferulic, coumaric, coumaroyl and resveratrol were also detected and quantified in strawberries (Table IV). All these compounds were found to be varied significantly in strawberry cultivars under different $\left[\mathrm{CO}_{2}\right]$, temperature and their interactions. Catechin is a monomeric flavanol, generally, reported difficult to be detected ${ }^{51}$. When $\left[\mathrm{CO}_{2}\right]$ was elevated from 400 to $950 \mu \mathrm{moL} / \mathrm{moL}$ in growth environment, catechin content of fruits increased gradually from $9 \pm 1.6$ to $43 \pm 5.8 \mathrm{mg} / \mathrm{kg} \mathrm{FW}$ and $8 \pm 0.8$ to $58 \pm 4.3 \mathrm{mg} / \mathrm{kg} \mathrm{FW}$ in 'Albion' and 'SA', respectively. Higher temperature also affected positively on catechin content of fruits in both strawberry cultivars only under elevated $\left[\mathrm{CO}_{2}\right]$. The interaction of $\mathrm{e}\left[\mathrm{CO}_{2}\right]$, temperature and cultivar was statistically significant $(\mathrm{P}<0.05)$. Increased temperature by $5{ }^{\circ} \mathrm{C}$ than $25{ }^{\circ} \mathrm{C}$ interactively with 650 and $950 \mu \mathrm{moL} / \mathrm{moL}\left[\mathrm{CO}_{2}\right]$ enhanced catechin concentrations in strawberry cultivar 'Albion'. However, higher temperature showed negative impact on the catechin content of fruits in cultivar 'SA' at 950 $\mu \mathrm{moL} / \mathrm{moL}$. Moreover, cultivar 'SA'contained comparatively higher catechin contents than 'Albion' under all $\mathrm{e}\left[\mathrm{CO}_{2}\right]$ and higher temperature conditions. 
Increased temperature significantly influenced on the ferulic acid content of strawberries (Table IV). Ferulic acid content of strawberries showed changes in pattern compared with catechin, with the maximum detected quantities of $63 \pm 4$ and $67 \pm 3 \mathrm{mg} / \mathrm{kg} \mathrm{FW}$ in cultivar 'Albion' and 'SA' respectively, at $400 \mu \mathrm{moL} / \mathrm{moL} \mathrm{CO} 2$ and $30{ }^{\circ} \mathrm{C}$. Consequently, increasing the $\left[\mathrm{CO}_{2}\right]$ above the $400 \mu \mathrm{moL} / \mathrm{moL}$ would not have any significant effect on ferulic acid. However, the interaction of $\left[\mathrm{CO}_{2}\right]$, temperature and cultivar was significant on ferulic acid contents of fruits. The same results revealed that $\mathrm{e}\left[\mathrm{CO}_{2}\right]$ at higher temperature caused negative effects on strawberries. Coumaroyl contents ranged from $4.4 \pm 0.4$ to $14 \pm 1.6$ $\mathrm{mg} / \mathrm{kg}$ FW for cultivar 'Albion' and from $4.4 \pm 0.3$ to $15.4 \pm 0.7 \mathrm{mg} / \mathrm{kg} \mathrm{FW}$ for cultivar 'SA'. The lowest coumaroyl contents were detected under $400 \mu \mathrm{moL} / \mathrm{moL}$ and $25{ }^{\circ} \mathrm{C}$ and the highest under highest $\mathrm{e}\left[\mathrm{CO}_{2}\right]$ and higher temperature. In previous studies, higher contents of $p$-coumaroyl glucose was reported in strawberry grown under high temperature $\left(30^{\circ} \mathrm{C}\right){ }^{21}$ and enriched $\left[\mathrm{CO}_{2}\right]^{33}$. Greater amounts of coumaroyl derivatives were also detected in grapes grown under high growth temperatures ${ }^{52,53}$.

Resveratrol is a stilbene polyphenol and is available only in a few plant sources including strawberries in smaller quantities. As far as resveratrol is concerned, its synthesis can be successfully induced in plants using molecular engineering techniques ${ }^{54}$. From all the polyphenol compounds identified in this study, resveratrol had the lowest quantities in strawberry. The resveratrol content in strawberry varied from $23 \pm 1$ to $113 \pm 5 \mu \mathrm{g} / \mathrm{kg} \mathrm{FW}$ and from $23 \pm 2$ to $82 \pm 6 \mu \mathrm{g} / \mathrm{kg} \mathrm{FW}$ in 'Albion' and 'SA', respectively. Elevated $\left[\mathrm{CO}_{2}\right]$ and high temperature individually and interactively enhanced the resveratrol contents in strawberries. However, 'Albion' revealed the highest resveratrol content under $950 \mu \mathrm{moL} / \mathrm{moL}$ and 30 ${ }^{\circ} \mathrm{C}$ and 'SA' under $650 \mu \mathrm{moL} / \mathrm{moL}$ and $30{ }^{\circ} \mathrm{C}$. Similar observation were reported by Wang et al. ${ }^{34}$ who demonstrated an increase in resveratrol contents in strawberries under high growth temperatures (25 and $30{ }^{\circ} \mathrm{C}$ ) or under enriched $\left[\mathrm{CO}_{2}\right]$ by $600 \mu \mathrm{moL} / \mathrm{moL}$ in the growth environment than under ambient 
growth conditions. In current study, resveratrol content was increased in in strawberries under both $\mathrm{e}\left[\mathrm{CO}_{2}\right]$ and temperature compared to the strawberries grown under $400 \mu \mathrm{moL} / \mathrm{moL}$ and $25{ }^{\circ} \mathrm{C}$ temperature. Similar to other polyphenols, resveratrol can contribute significantly to the antioxidant contents in strawberry fruits. Resveratrol has also been linked to many health benefits in humans including, preventing and delaying cancers, cardiovascular diseases, heart diseases, pathological inflammations, viral infections, and tumors ${ }^{54}$. Therefore resveratrol produces no harm even when the intake is high ${ }^{55}$. All these phenolic compounds express antagonistic and synergistic activities interactively with other polyphenols and/or phytochemicals in fruits ${ }^{40}$ and could increase the biological potential of strawberry.

The positive impacts of e $\left[\mathrm{CO}_{2}\right] 650$ and $950 \mu \mathrm{moL} / \mathrm{moL}$ and higher temperature $\left(30^{\circ} \mathrm{C}\right)$ individually and interactively on the contents of individual polyphenols in strawberries have been well established in this investigation. These findings are in agreement with the reported literature, which indicates that under optimal growth conditions, plants promote biomass production and reduce the biosynthesis of secondary metabolites ${ }^{56}$. However, plants stimulate the production of secondary metabolites as a defensive response to the environmental stresses ${ }^{46}$. The biosynthesis of polyphenols starts from phenylalanine to produce phenylpropanoid ${ }^{57}$. $P$-coumaroyl CoA and malonyl CoA are derived from phenylpropanoid and they are the precursors of flavonoid biosynthesis and different enzymes are involved in synthesising major flavonoid classes ${ }^{45}$. These key enzymes usually compete for the same substrate to produce different flavonoid compounds. Generally, the ultimate product of phenylpropanoid pathway is anthocyanin; however, it branches in the middle and, other polyphenols including stilbenes and lignin are synthesised ${ }^{58}$. The synthesis of these compounds was reported to be sensitive to the stresses in the growth environment ${ }^{57,59}$. 
However, the degree of stress accounts for different secondary metabolites and their varied quantities in plants ${ }^{58}$. In this study, higher temperature $\left(30^{\circ} \mathrm{C}\right)$ in the growth environment individually and interactively with $\mathrm{e}\left[\mathrm{CO}_{2}\right]$ encouraged the increase of individual polyphenols in different quantities in strawberry. Increasing the temperature in the growth environment would increase the synthesis and accumulation of polyphenolic compounds in response to the increased rate of metabolic processes in plant ${ }^{58}$. However, high temperature could also stop or significantly reduce the metabolic processes in some plants due to the irreversible damages to the plant tissues. These irreversible damages to some plants by heat could be varied in different plant species and cultivars. For example, Downey ${ }^{58}$ observed that some phenolic compounds were decreased or stable at high temperature $\left(30{ }^{\circ} \mathrm{C}\right)$ in grapes.

Similarly, high $\left[\mathrm{CO}_{2}\right]$ in the growth environment can increase the carbon supply where it promotes higher carbon availability in plants and accumulates more of carbohydrates ${ }^{60}$. These carbohydrates are firstly utilised in plant growth and then the excess amounts are used in the synthesis of carbon based secondary products specially soluble phenols and condensed tannins ${ }^{61}$.

In summary, stress growth conditions, $\mathrm{e}\left[\mathrm{CO}_{2}\right](650$ and $950 \mu \mathrm{moL} / \mathrm{moL})$ and /or higher temperature $(30$ ${ }^{\circ} \mathrm{C}$ ), can encourage the synthesis and accumulation of phenolic compounds and significantly enhance the corresponding antioxidant properties. Although, a previous study in our lab ${ }^{36}$ showed that strawberry fruits had lower yields and physical quality under stress growth conditions, results from this current investigation revealed that strawberry fruits were rich with polyphenols and antioxidants under $\mathrm{e}\left[\mathrm{CO}_{2}\right]$ $(950 \mu \mathrm{moL} / \mathrm{moL})$ and higher temperature $\left(30{ }^{\circ} \mathrm{C}\right)$ conditions. The increase contents of total and individual polyphenols and antioxidants of strawberry fruits will be highly beneficial to human health.

\section{Acknowledgments}


The Authors greatly acknowledge and appreciate the contribution and effort provided by Bruce Tomkins throughout this investigation. The 2017 Innovation Seed Fund for Horticulture Development of The University of Melbourne and Department of Economic Development, Jobs, Transport and Resources (DEDJTR) provided the financial assistance for this project.

\section{References}

(1). Vijayan, Vijayan K, Chakraborti S, Ercisli S and Ghosh PD. Na $\mathrm{Cl}$ induced morpho-biochemical and anatomical changes in mulberry (Morus spp.). 2008, 56, 1, 61-9.

(2). Serce S, Ercisli S, Sengul M, Gunduz K and Orhan E. Antioxidant activities and fatty acid composition of wild grown myrtle (Myrtus communis L.) fruits. 2010, 6, 21, 9-12.

(3). Tian, Tian J, Chen J, Ye X and Chen S. Health benefits of the potato affected by domestic cooking: A review. 2016, 202, 165-75.

(4). Giampieri F, Alvarez Suarez J, Mazzoni L, Romandini S, Bompadre S, Diamanti J, Capocasa F, Mezzetti B, Quiles J, Ferreiro M, Tulipani S and Battino M. The potential impact of strawberry on human health. Nat Prod Res. 2013, 27, 4-5, 448-55.

(5). Afrin S, Gasparrini M, Forbes Hernandez T, Reboredo Rodriguez P, Mezzetti B, Varela López A, Giampieri F and Battino M. Promising health benefits of the strawberry: A focus on clinical studies. $2016,64,22,4435-49$.

(6). Giampieri F, Forbes Hernandez T, Gasparrini M, Alvarez Suarez J, Afrin S, Bompadre S, Quiles J, Mezzetti B and Battino M. Strawberry as a health promoter: An evidence based review. Food Funct. $2015,6,5,1386-98$.

(7). Giampieri F, Alvarez Suarez J and Battino M. Strawberry and human health: Effects beyond antioxidant activity. J Agric Food Chem. 2014, 62, 18, 3867-76. 
(8). Giampieri F, Tulipani S, Alvarez-Suarez JM, Quiles JL, Mezzetti B and Battino M. The strawberry: Composition, nutritional quality, and impact on human health. Nutr. 2012, 28, 1, 9-19.

(9). Aaby K, Ekeberg D and Skrede G. Characterization of phenolic compounds in strawberry (Fragaria a -ananassa) fruits by different hplc detectors and contribution of individual compounds to total antioxidant capacity. 2007, 55, 11, 4395-406.

(10). Dai J and Mumper R. Plant phenolics: Extraction, analysis and their antioxidant and anticancer properties. Molecules. 2010, 15, 10, 7313-52.

(11). da Silva FL, Escribano-Bailón MT, Pérez Alonso JJ, Rivas-Gonzalo JC and Santos-Buelga C. Anthocyanin pigments in strawberry. Food Sci Technol. 2007, 40, 2, 374-82.

(12). Aaby K, Mazur S, Nes A and Skrede G. Phenolic compounds in strawberry (Fragaria $x$ ananassa duch.) fruits: Composition in 27 cultivars and changes during ripening. Food Chem. 2012, $132,1,86-97$.

(13). La Barbera G, Capriotti A, Cavaliere C, Piovesana S, Samperi R, Zenezini Chiozzi R and Laganà A. Comprehensive polyphenol profiling of a strawberry extract (Fragaria $\times$ ananassa) by ultrahigh-performance liquid chromatography coupled with high-resolution mass spectrometry. Anal Bioanal Chem. 2017, 409, 8, 2127-42.

(14). Capocasa F, Scalzo J, Mezzetti B and Battino M. Combining quality and antioxidant attributes in the strawberry: The role of genotype. Food Chem. 2008, 111, 4, 872-8.

(15). Diamanti J, Capocasa F, Mezzetti B, Tulipani S and Battino M. The interaction of plant genotype and temperature conditions at ripening stage affects strawberry nutritional quality. Acta Hortic. 2008, 838, 183-6.

(16). Kosar M, Kafkas E, Paydas S and Baser KHC. Phenolic composition of strawberry genotypes at different maturation stages. J Agric Food Chem. 2004, 52, 6, 1586-9. 
(17). Palmieri L, Masuero D, Martinatti P, Baratto G, Martens S and Vrhovsek U. Genotype-byenvironment effect on bioactive compounds in strawberry (Fragaria x ananassa Duch.). J Sci Food Agric. 2017, 97, 12, 4180-9.

(18). Tulipani S, Mezzetti B, Capocasa F, Bompadre S, Beekwilder J, de Vos CHR, Capanoglu E, Bovy A and Battino M. Antioxidants, phenolic compounds, and nutritional quality of different strawberry genotypes. J Agric Food Chem. 2008, 56, 3, 696-704.

(19). Tulipani S, Romandini S, Battino M, Bompadre S, Capocasa F and Mezzetti B, editors. "Variation in strawberry micronutrients, phytochemical and antioxidant profiles: The combined effect of genotype and storage". VI International Strawberry Symposium 842; 2008.

(20). Wang SY. "Antioxidant capacity and phenolic content of berry fruits as affected by genotype, pre-harvest conditions, maturity and post-harvest handling". In: Zhao Y, editor. Berry fruit: Value-added products for health promotion. 1 ed. Boca Raton, CRC Press; 2007. pp. 147-86.

(21). Wang S and Zheng W. Effect of plant growth temperature on antioxidant capacity in strawberry. J Agric Food Chem. 2001, 49, 10, 4977-82.

(22). Crecente-Campo J, Nunes-Damaceno M, Romero-Rodríguez MA and Vázquez-Odériz ML. Color, anthocyanin pigment, ascorbic acid and total phenolic compound determination in organic versus conventional strawberries (Fragaria $\times$ ananassa Duch, cv Selva). J Food Compost Anal. 2012, 28, 1, 2330.

(23). de Jesus Ornelas-Paz J, Ornelas-Paz JdJ, Yahia E, Ramirez Bustamante N, Perez Martinez J, Escalante-Minakata MdP, Ibarra Junquera V, Acosta Muniz C, Guerrero Prieto V and Ochoa Reyes E. Physical attributes and chemical composition of organic strawberry fruit (Fragaria $x$ ananassa Duch, cv. Albion) at six stages of ripening. 2013, 138, 1, 372-81. 
(24). Sun P, Mantri N, Lou H, Hu Y, Sun D, Zhu Y, Dong T and Lu H. Effects of elevated $\mathrm{CO}_{2}$ and temperature on yield and fruit quality of strawberry (Fragaria $\times$ ananassa Duch.) at two levels of nitrogen application. PLoS One. 2012, 7, 7, e41000.

(25). Yoshida Y, Koyama N and Tamura H. Color and anthocyanin composition of strawberry fruit. Changes during fruit development and differences among cultivars, with special reference to the occurrence of pelargonidin 3-malonylglucoside. J Jpn Soc Hort Sci. 2002, 71, 3, 355-61.

(26). IPCC. "Climate change 2014 synthesis report, summary for policymakers". 2014. pp.

(27). IPCC. Carbon dioxide: Projected emissions and concentrations, Intergovermental Pannel on Climate Change; 2001 [updated 04/04/2014.

(28). IPCC. "Climate change 2007: The physical science basis. Contribution of working group I to the fourth assessment report of the intergovernmental panel on climate change". Cambridge, 2007. pp. 996. (29). IPCC. "Climate change 2014: Synthesis report. Contribution of working groups I, II and III to the fifth assessment report of the intergovernmental panel on climate change". IPCC, Geneva, Switzerland, 2014. pp. 151.

(30). Kizildeniz T, Mekni I, Santesteban H, Pascual I, Morales F and Irigoyen JJ. Effects of climate change including elevated $\mathrm{CO}_{2}$ concentration, temperature and water deficit on growth, water status, and yield quality of grapevine (Vitis vinifera L.) cultivars. 2015, 159, 155-64.

(31). Calleja EJ. The potential impacts of climate change on diseases affecting strawberries and the uk strawberry industry, University of Warwick; 2011.

(32). Wang S and Camp M. Temperatures after bloom affect plant growth and fruit quality of strawberry. Sci Hort. 2000, 85, 3, 183-99.

(33). Wang S, Bunce J and Maas JL. Elevated carbon dioxide increases contents of antioxidant compounds in field-grown strawberries. J Agric Food Chem. 2003, 51, 15, 4315-20. 
(34). Wang S, Chen C-T, Wang C and Chen P. Resveratrol content in strawberry fruit is affected by preharvest conditions. J Agric Food Chem. 2007, 55, 20, 8269-74.

(35). Balasooriya HN, Dassanayake KB, Tomkins B, Seneweera S and Ajlouni S. Impacts of elevated carbon dioxide and temperature on physicochemical and nutrient properties in strawberries. J Hortic Sci Biotech. 2017, 1, 1, 19-29.

(36). Balasooriya HN, Dassanayake KB, Seneweera S and Ajlouni S. Interaction of elevated carbon dioxide and temperature on strawberry (Fragaria $\times$ ananassa) growth and fruit yield. Int J Biol Biomol Agri Food Biotechnol Eng. 2018, 12, 9, 279-87.

(37). Tow W, Premier R, Jing $\mathrm{H}$ and Ajlouni S. Antioxidant and antiproliferation effects of extractable and nonextractable polyphenols isolated from apple waste using different extraction methods. J Food Sci. 2011, 76, 7, T163-T72.

(38). Re R, Pellegrini N, Proteggente A, Pannala A, Yang M and Rice Evans C. Antioxidant activity applying an improved abts radical cation decolorization assay. Free Radic Biol Med. 1999, 26, 9-10, $1231-7$.

(39). Giusti MM and Wrolstad RE. Characterization and measurement of anthocyanins by UV-visible spectroscopy. Current Protocols in Food Analytical Chemistry. 2001, F:F1:F.2.

(40). Meyers K, Watkins C, Pritts M and Liu R. Antioxidant and antiproliferative activities of strawberries. J Agric Food Chem. 2003, 51, 23, 6887-92.

(41). Balasooriya HN, Dassanayake KB and Ajlouni S, editors. "High temperature effects on strawberry fruit quality and antioxidant contents". Proceedings of the 4th Internaltional Conference on Postharvest and Quality Management of Horticultural Products of Interest for Tropical Regions; 2017; Kandy, Sri Lanka, Acta Horticulturae, International Society for Horticultural Sciences. 
(42). Wang S and Lin H-S. Antioxidant activity in fruits and leaves of blackberry, raspberry, and strawberry varies with cultivar and developmental stage. J Agric Food Chem. 2000, 48, 2, 140-6.

(43). Ghasemi K, Ghasemi Y and Ebrahimzadeh MA. Antioxidant activity, phenol and flavonoid contents of 13 citrus species peels and tissues. 2009, 22, 3, 277-81.

(44). Dyduch SiemiDska M, Najda A, Dyduch J, Gantner M and Klimek K. The content of secondary metabolites and antioxidant activity of wild strawberry fruit (Fragaria vesca L.). 2015, 2015, 1-8.

(45). Winkel Shirley B. Biosynthesis of flavonoids and effects of stress. Curr Opin Plant Biol. 2002, 5, $3,218-23$.

(46). Atkinson CJ, Nestby R, Ford YY and Dodds PAA. Enhancing beneficial antioxidants in fruits: A plant physiological perspective. Biofactors. 2005, 23, 4, 229-34.

(47). Ariza MT, Martínez Ferri E, Domínguez P, Medina JJ, Miranda L and Soria C. Effects of harvest time on functional compounds and fruit antioxidant capacity in ten strawberry cultivars. J Berry Res. 2015, 5, 2, 71-80.

(48). Basu A, Nguyen A, Betts N and Lyons T. Strawberry as a functional food: An evidence-based review. Critical reviews in food science and nutrition. 2014, 54, 6, 790-806.

(49). Aaby K, Skrede G and Wrolstad R. Phenolic composition and antioxidant activities in flesh and achenes of strawberries (Fragaria ananassa). J Agric Food Chem. 2005, 53, 10, 4032-40.

(50). Sharma $\mathrm{P}$, Jha $\mathrm{AB}$ and Dubey RS. In Oxidative stress and antioxidative defense systems in plants growing under abiotic stresses : Handbook of plant and crop stress. Series, 3; Tan KH and Pessarakli M; Eds. CRC Press: Baton Rouge, United States, 2010; Vol. pp. 1248.

(51). Hannum SM. Potential impact of strawberries on human health: A review of the science. Critical reviews in food science and nutrition. 2004, 44, 1, 1-17. 
(52). Downey M, Harvey J and Robinson S. The effect of bunch shading on berry development and flavonoid accumulation in shiraz grapes. 2004, 10, 1, 55-73.

(53). Spayd SE. Separation of sunlight and temperature effects on the composition of Vitis vinifera cv. Merlot berries. Am J Enology Vitic. 2002, 53, 3, 171.

(54). Halls $\mathrm{C}$ and $\mathrm{Yu} \mathrm{O}$. Potential for metabolic engineering of resveratrol biosynthesis. Trends Biotechnol. 2008, 26, 2, 77-81.

(55). Charles DJ. In Antioxidant properties of spices, herbs and other sources. Springer Science \& Business Media: Frontier Natural Products Co-op Norway, IA , USA. 2012.

(56). Carter E, Theodorou M and Morris P. Responses oflotus corniculatus to environmental change. 2. Effect of elevated $\mathrm{CO}_{2}$, temperature and drought on tissue digestion in relation to condensed tannin and carbohydrate accumulation. J Sci Food Agric. 1999, 79, 11, 1431-40.

(57). Dixon RA and Paiva NL. Stress-induced phenylpropanoid metabolism. Plant Cell. 1995, 7, 7, 1085-97.

(58). Downey MO. Cultural practice and environmental impacts on the flavonoid composition of grapes and wine: A review of recent research. Am J Enol Viticul. 2006, 57, 3, 257.

(59). Giovinazzo G, Ingrosso I, Paradiso A, De Gara L and Santino A. Resveratrol biosynthesis: Plant metabolic engineering for nutritional improvement of food. Plant Foods Hum Nutr. 2012, 67, 3, 191-9.

(60). Kumari S, Agrawal $\mathrm{M}$ and Tiwari S. Impact of elevated $\mathrm{CO}_{2}$ and elevated $\mathrm{O}_{3}$ on Beta vulgaris L.: Pigments, metabolites, antioxidants, growth and yield. Environ Pollut. 2013, 174, 279-88.

(61). Penuelas $\mathrm{J}$ and Estiarte $\mathrm{M}$. Can elevated $\mathrm{CO}_{2}$ affect secondary metabolism and ecosystem function? Trends Ecol Evol. 1998, 13, 1, 20-4.

\section{Figure Legends}

This article is protected by copyright. All rights reserved. 
Figure I. Total polyphenolic contents (TPC) of two different strawberry cultivars ('Albion' and 'San Andreas') at different combinations of temperature and $\left[\mathrm{CO}_{2}\right]$. Error bars refer to standard deviation of data $(\mathrm{n}=12)$. Different letters in both cultivars and within each $\mathrm{CO}_{2}$ concentration are significantly $(\mathrm{p} \mathrm{d}$ $0.05)$ different.

Figure II. Total flavonoid contents (TFC) of two different strawberry cultivars ('Albion' and 'San Andreas') at different combinations of temperature and $\left[\mathrm{CO}_{2}\right]$. Error bars refer to standard deviation of data $(\mathrm{n}=12)$. Different letters in both cultivars and within each $\mathrm{CO}_{2}$ concentration are significantly ( $\mathrm{p} \mathrm{d}$ $0.05)$ different.

Figure III. Total monomeric anthocyanin contents (TMAC) of two different strawberry cultivars ('Albion' and 'San Andreas') at different combinations of temperature and $\left[\mathrm{CO}_{2}\right]$. Error bars refer to standard deviation of data $(n=12)$. Different letters in both graphs are significantly ( $\mathrm{p} \mathrm{d} 0.05)$ different.

Figure IV. Total antioxidant contents (TAC) ( $\mu \mathrm{moL}$ Trolox equivalents per $\mathrm{g}$ of $\mathrm{FW}$ ) of two different strawberry cultivars ('Albion' and 'San Andreas') at different combinations of temperature and $\left[\mathrm{CO}_{2}\right]$. Error bars refer to standard deviation of data $(n=12)$. Different letters in both graphs are significantly $(p$ d 0.05) different.

Figure V. HPLC chromatographs of polyphenols of strawberries obtained at 280, 320, 360 and $510 \mathrm{~nm}$. 1. Catechin, 2. Unknown, 3. Pelargonidin-3-Glucoside (Pel-3-Glu), 4. Pelargonidin-3-Rutinoside (Pel-3Rut), 5. Cyanidin, 6. Quercetin-3,4-di Glucoside (Q-3,4-diGlu), 7. p-Coumaric, 8. Ferulic acid, 9. Quercetin-3-O-Glucuronide (Q-3-O-Glu'nide), 10. Coumaroyl, 11. Kaempferol-3-Glucoside (K-3-Glu), 12

Kaempferol-3-Glucuronide

(K-3-Glu'nide),

and

13.

Resveratrol 
Figure I

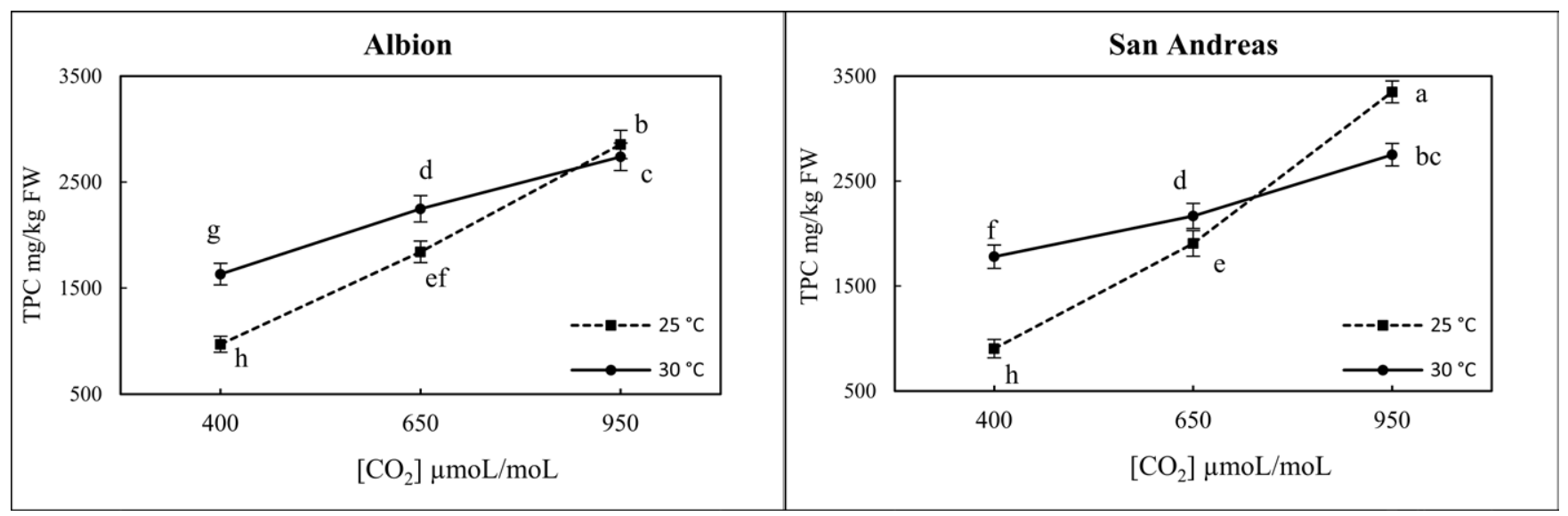

Figure II

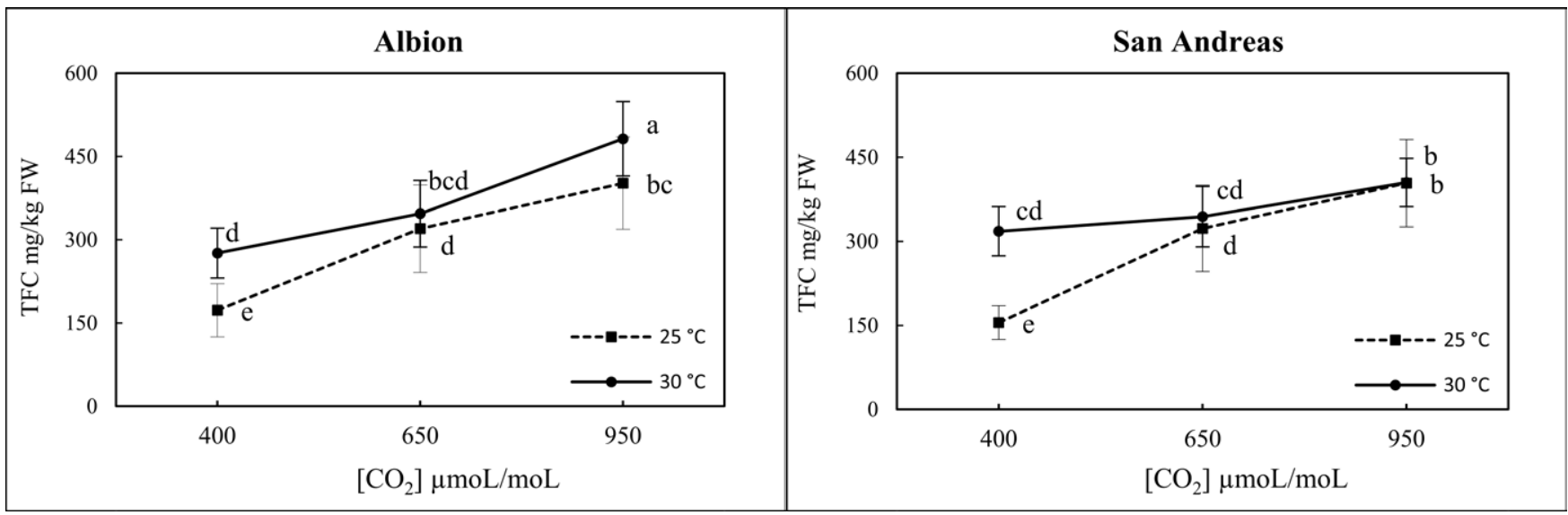

\section{Figure III}

This article is protected by copyright. All rights reserved. 

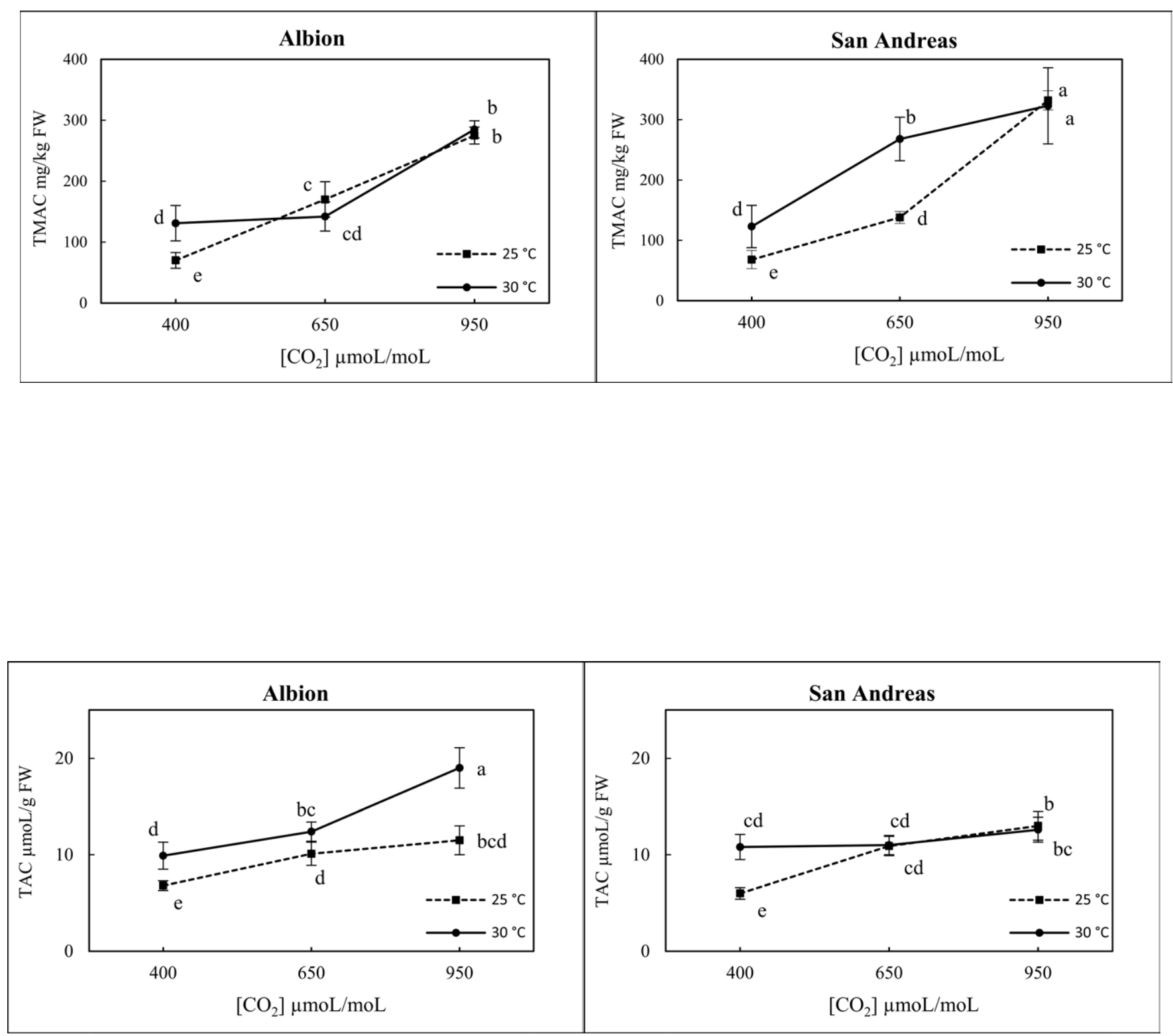

Figure IV

This article is protected by copyright. All rights reserved. 
Figure V

This article is protected by copyright. All rights reserved. 

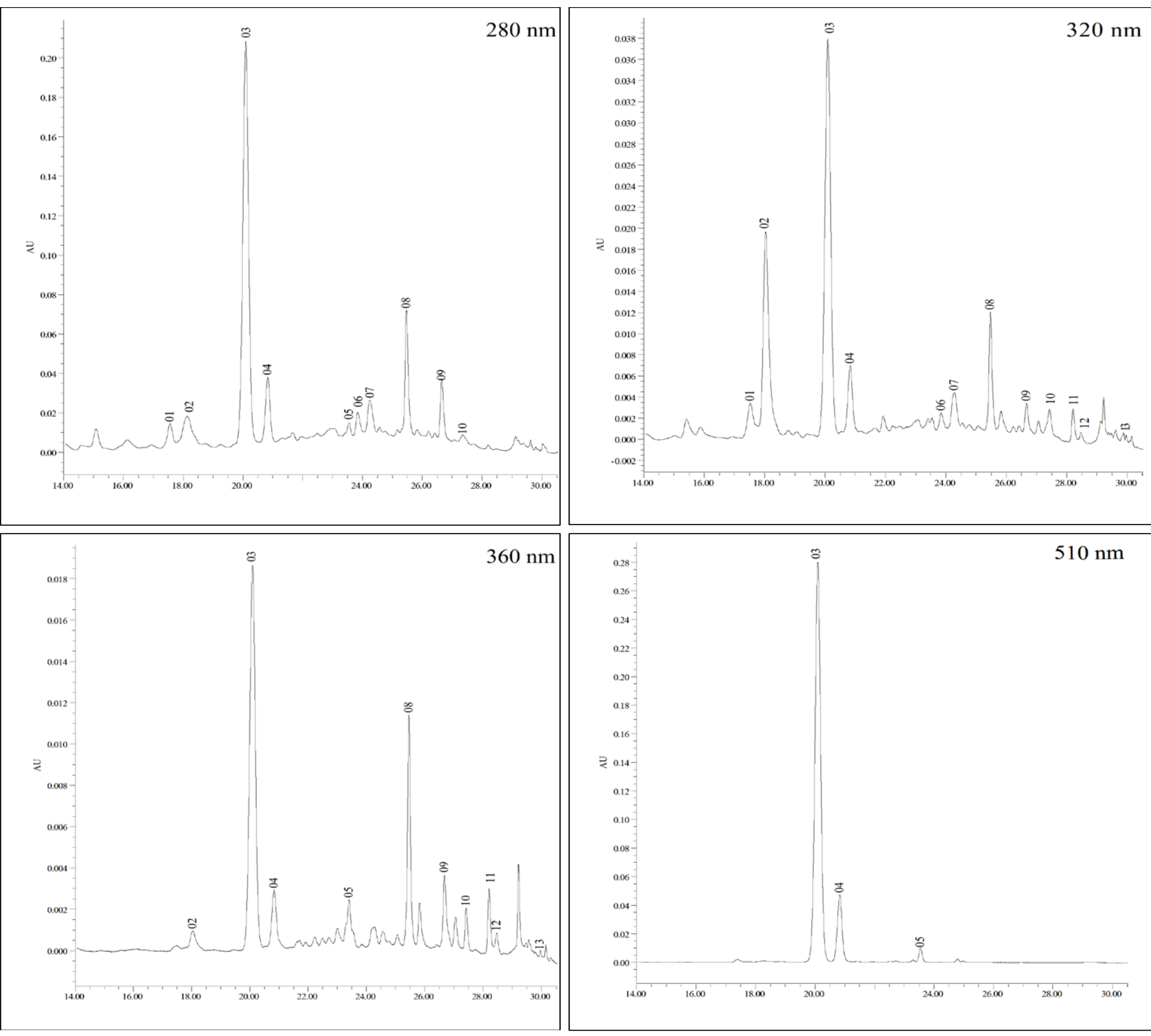
Table I. Pearson's correlation matrix between TPC, TFC and TMAC in strawberry cultivars

\begin{tabular}{lccc}
\hline Variable & TPC & TFC & TMAC \\
\hline TFC & $0.919^{* *}$ & & \\
TMAC & $0.922^{* *}$ & $0.851^{* *}$ & \\
TAC & $0.789^{*}$ & $0.937^{* *}$ & $0.729 *$ \\
\hline
\end{tabular}

Values are Pearson correlation coefficients.

* - significant correlation at $\mathrm{p} \mathrm{d} 0.05,{ }^{* *}$ - significant correlation at $\mathrm{p} \mathrm{d} 0.001$

Table I

This article is protected by copyright. All rights reserved. 
Table II. Identification of strawberry polyphenols

$\begin{array}{llll}\text { Peak } & \text { Polyphenol Compound } & \text { RT (Minutes) } & »(\mathrm{~nm}) \\ 01 & \text { Catechin } & 17.5 \pm 0.03 & 280 \\ 02 & \text { Unknown } & 18.2 \pm 0.30 & 280 \\ 03 & \text { Pelargonidin-3-Glucoside (Pel-3-Glu) } & 20.0 \pm 0.16 & 510 \\ 04 & \text { Pelargonidin-3-Rutinoside (Pel-3Rut) } & 20.8 \pm 0.12 & 510 \\ 05 & \text { Cyanidin } & 23.5 \pm 0.21 & 510 \\ 06 & \text { Quercetin-3,4-di Glucoside (Q-3,4-diGlu) } & 23.8 \pm 0.26 & 280 \\ 07 & \text { p-Coumaric } & 24.2 \pm 0.80 & 280 \\ 08 & \text { Ferulic acid } & 25.4 \pm 0.21 & 280 \\ 09 & \text { Quercetin-3-O-Glucuronide (Q-3-O-Glu'nide) } & 26.8 \pm 0.21 & 280 \\ 10 & \text { Coumaroyl } & 27.4 \pm 0.22 & 280 \\ 11 & \text { Kaempferol-3-Glucoside (K-3-Glu) } & 28.3 \pm 0.28 & 360 \\ 12 & \text { Kaempferol-3-Glucuronide (K-3-Glu'nide) } & 28.7 \pm 0.26 & 360 \\ 13 & \text { Resveratrol } & 29.9 \pm 0.31 & 320\end{array}$

Different polyphenol compounds were identified in a range of $200-600 \mathrm{~nm}$ wavelength. » - specific wavelength of compound quantification, RT - retention time (Mean $\pm \mathrm{SD}$ )

\section{Table II}

This article is protected by copyright. All rights reserved. 
Table III

This article is protected by copyright. All rights reserved. 
Table IV

This article is protected by copyright. All rights reserved. 
Figure I

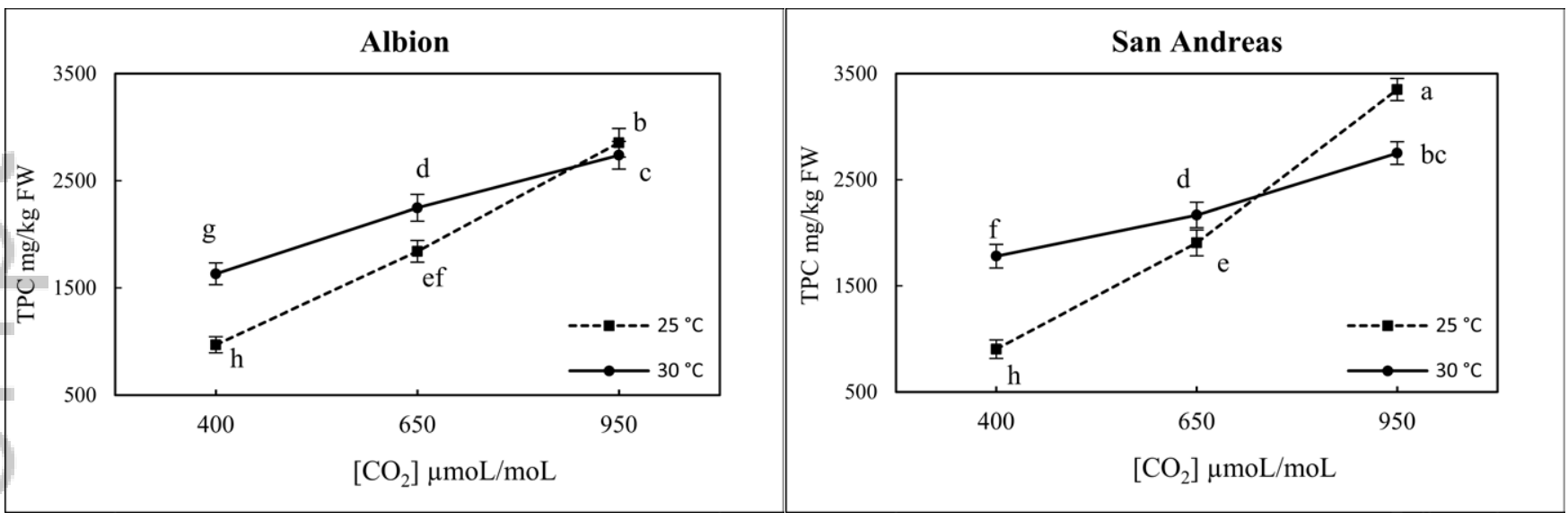

This article is protected by copyright. All rights reserved. 
Figure II

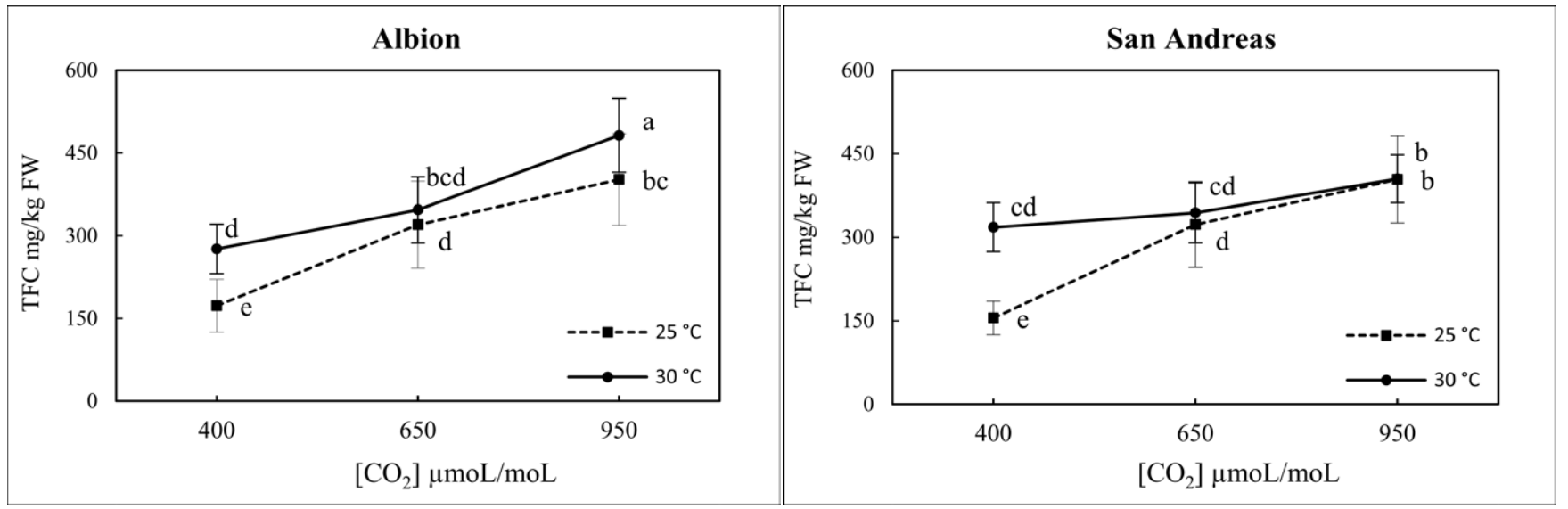

This article is protected by copyright. All rights reserved. 


\section{Figure III}

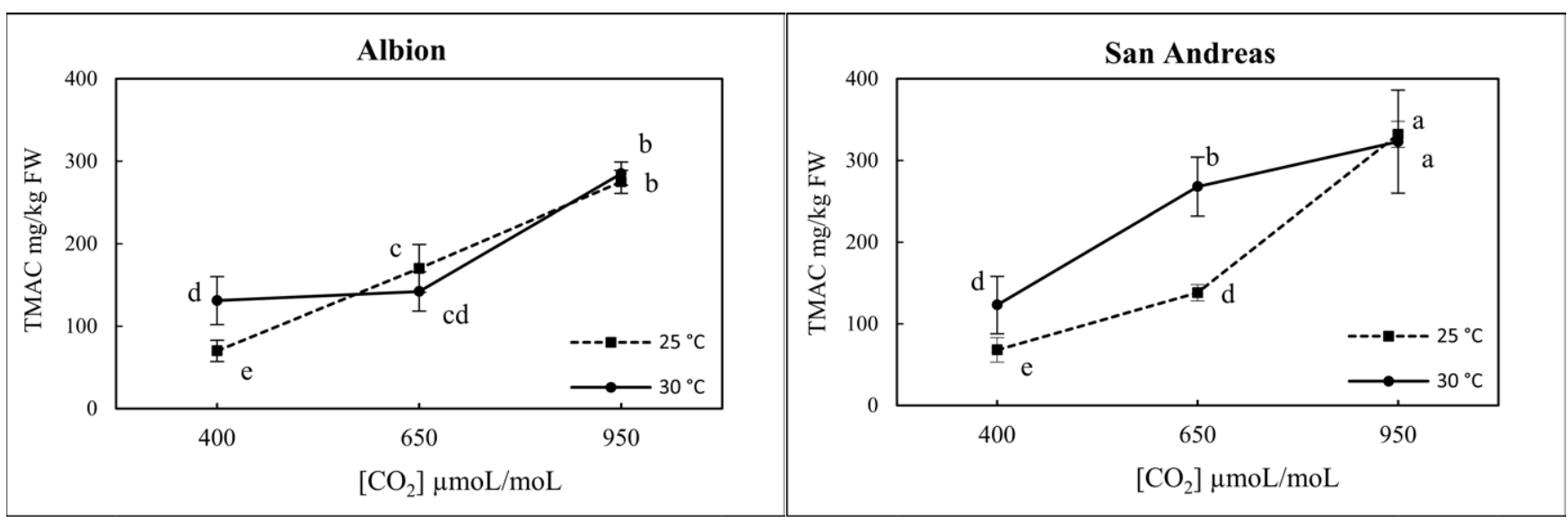

This article is protected by copyright. All rights reserved. 
Figure IV

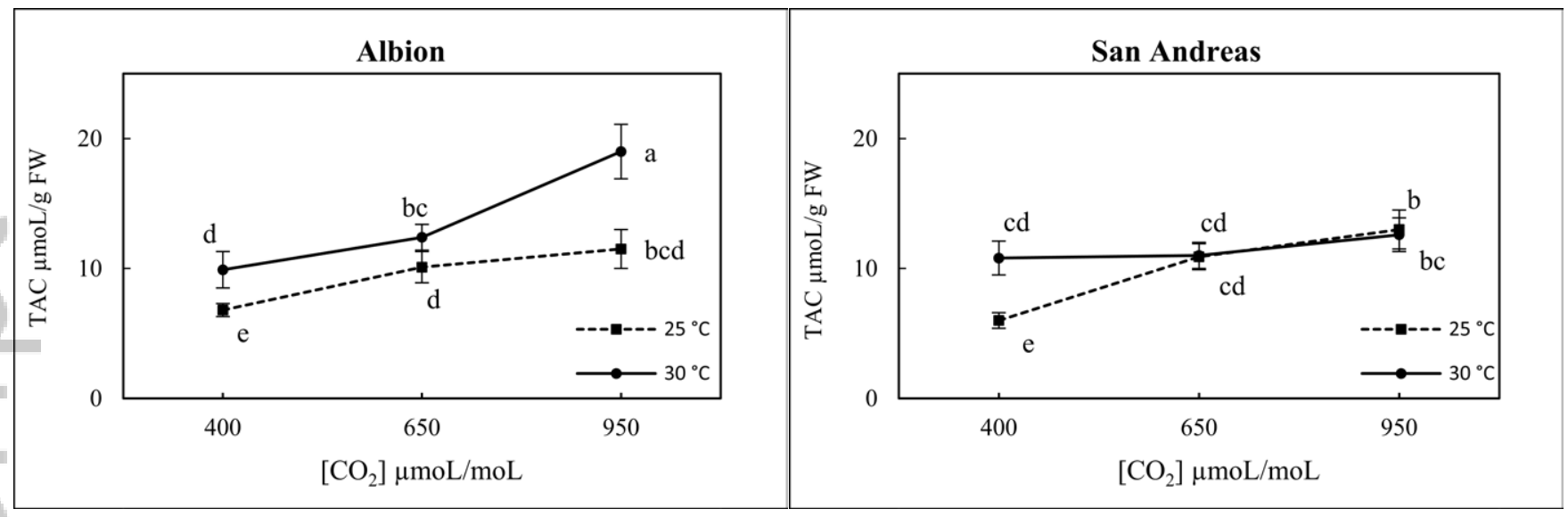

This article is protected by copyright. All rights reserved. 


\section{Figure V}
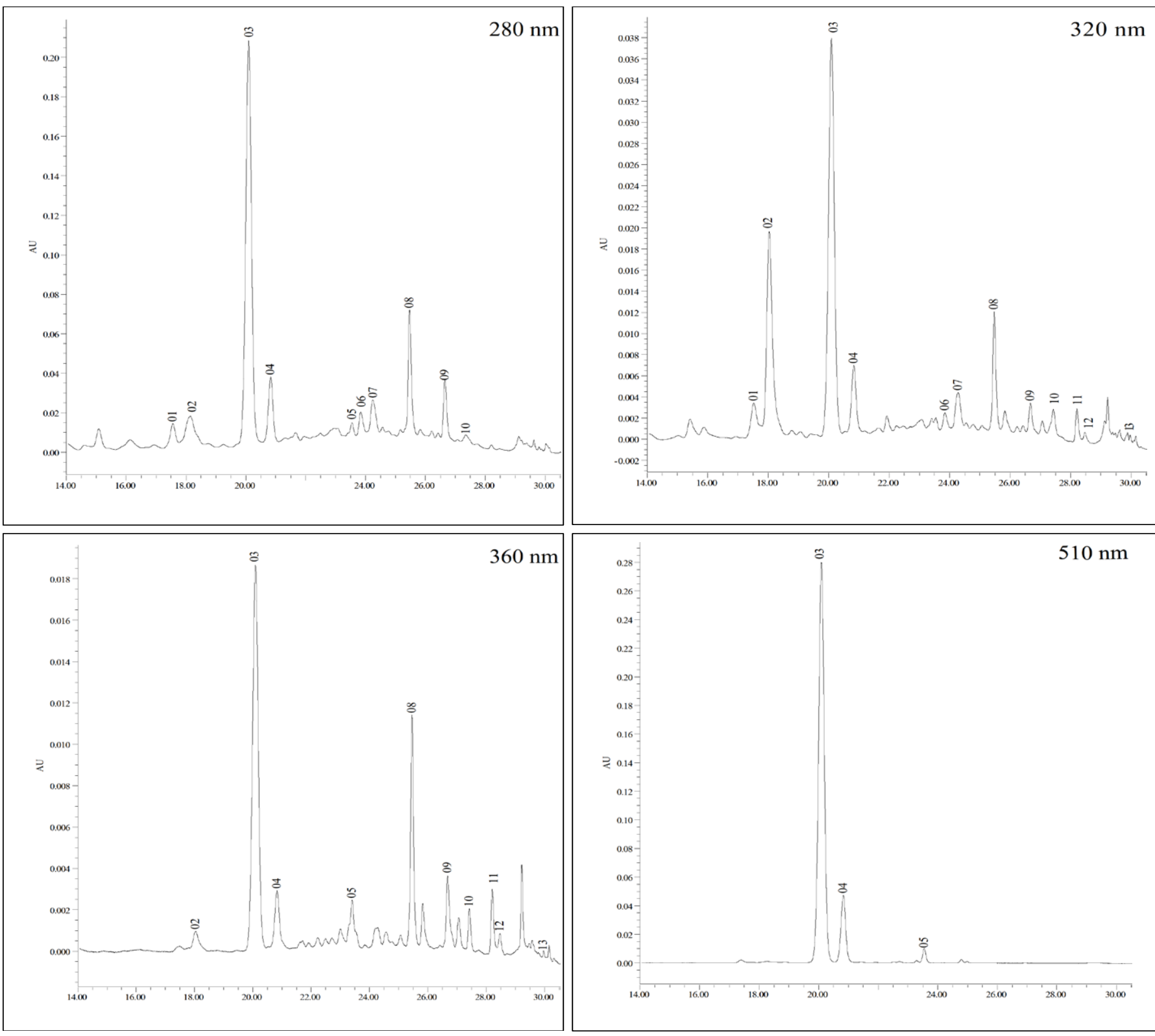

This article is protected by copyright. All rights reserved. 
Table I

Table I. Pearson's correlation matrix between TPC, TFC and TMAC in strawberry cultivars

\begin{tabular}{lccc}
\hline Variable & TPC & TFC & TMAC \\
\hline TFC & $0.919^{* *}$ & & \\
TMAC & $0.922^{* *}$ & $0.851^{* *}$ & \\
TAC & $0.789^{*}$ & $0.937^{* *}$ & $0.729^{*}$ \\
\hline
\end{tabular}

Values are Pearson correlation coefficients.

* - significant correlation at $\mathrm{p} \mathrm{d} 0.05, * *$ - significant correlation at $\mathrm{p} d 0.001$

This article is protected by copyright. All rights reserved. 


\section{Table II}

Table II. Identification of strawberry polyphenols

$\begin{array}{llll}\text { Peak } & \text { Polyphenol Compound } & \text { RT (Minutes) } & \text { »(nm) } \\ 01 & \text { Catechin } & 17.5 \pm 0.03 & 280 \\ 02 & \text { Unknown } & 18.2 \pm 0.30 & 280 \\ 03 & \text { Pelargonidin-3-Glucoside (Pel-3-Glu) } & 20.0 \pm 0.16 & 510 \\ 04 & \text { Pelargonidin-3-Rutinoside (Pel-3Rut) } & 20.8 \pm 0.12 & 510 \\ 05 & \text { Cyanidin } & 23.5 \pm 0.21 & 510 \\ 06 & \text { Quercetin-3,4-di Glucoside (Q-3,4-diGlu) } & 23.8 \pm 0.26 & 280 \\ 07 & \text { p-Coumaric } & 24.2 \pm 0.80 & 280 \\ 08 & \text { Ferulic acid } & 25.4 \pm 0.21 & 280 \\ 09 & \text { Quercetin-3-O-Glucuronide (Q-3-O-Glu'nide) } & 26.8 \pm 0.21 & 280 \\ 10 & \text { Coumaroyl } & 27.4 \pm 0.22 & 280 \\ 11 & \text { Kaempferol-3-Glucoside (K-3-Glu) } & 28.3 \pm 0.28 & 360 \\ 12 & \text { Kaempferol-3-Glucuronide (K-3-Glu'nide) } & 28.7 \pm 0.26 & 360 \\ 13 & \text { Resveratrol } & 29.9 \pm 0.31 & 320\end{array}$

Different polyphenol compounds were identified in a range of $200-600 \mathrm{~nm}$ wavelength. »-specific wavelength of compound quantification, RT - retention time (Mean $\pm \mathrm{SD}$ ) 


\section{Table III}

Table III. Effect of different temperature and $\left[\mathrm{CO}_{2}\right]$ on different anthocyanins and flavonols compounds in strawberry cultivars

\begin{tabular}{|c|c|c|c|c|c|c|c|c|c|}
\hline \multirow[b]{2}{*}{ Cultivar } & \multirow[b]{2}{*}{$\mathrm{T}$} & \multirow[b]{2}{*}[\mathrm{CO}_{2}]{} & \multicolumn{3}{|c|}{ Anthocyanins } & \multicolumn{4}{|c|}{ Flavonols } \\
\hline & & & Pel-3-Glu ${ }^{a}$ & Pel-3-Rut ${ }^{b}$ & Cyanidin $^{c}$ & $\begin{array}{l}\text { Q-3,4-di-O- } \\
\text { Glu'side }^{d}\end{array}$ & $\begin{array}{l}\text { Q-3-O- } \\
\text { Glu'nide }^{e}\end{array}$ & $\begin{array}{c}\text { K-3- } \\
\text { Glu'side }^{f}\end{array}$ & $\begin{array}{c}\text { K-3- } \\
\text { Glu'nide }^{g}\end{array}$ \\
\hline \multirow[t]{6}{*}{ Albion } & $25^{\circ} \mathrm{C}$ & 400 & $115 \pm 23 \mathrm{f}$ & $18 \pm 3 \mathrm{~g}$ & $27 \pm 4 \mathrm{~g}$ & $10.1 \pm 1.0 \mathrm{e}$ & $18 \pm 2 \mathrm{c}$ & $596 \pm 81 \mathrm{e}$ & $512 \pm 81 \mathrm{e}$ \\
\hline & & 650 & $177 \pm 29 \mathrm{~d}$ & $25 \pm 3$ ef & $79 \pm 13 \mathrm{~d}$ & $19.3 \pm 2.1 \mathrm{~b}$ & $6.3 \pm 0.8 \mathrm{~g}$ & $508 \pm 58 \mathrm{e}$ & $534 \pm 58 \mathrm{e}$ \\
\hline & & 950 & $273 \pm 30 \mathrm{~b}$ & $34 \pm 4 \mathrm{c}$ & $94 \pm 9 \mathrm{~d}$ & $24.6 \pm 3.4 \mathrm{a}$ & $20 \pm 3 \mathrm{c}$ & $1432 \pm 111 \mathrm{c}$ & $733 \pm 111 \mathrm{~d}$ \\
\hline & $30^{\circ} \mathrm{C}$ & 400 & $132 \pm 42$ ef & $29 \pm 4$ cde & $48 \pm 6 \mathrm{fg}$ & $20.1 \pm 1.5 \mathrm{~b}$ & $39 \pm 3 \mathrm{~b}$ & $619 \pm 69 \mathrm{de}$ & $624 \pm 69 \mathrm{de}$ \\
\hline & & 650 & $165 \pm 22 \mathrm{de}$ & $29 \pm 4 \mathrm{~d}$ & $61 \pm 4$ ef & $24.8 \pm 2.8 \mathrm{a}$ & $13 \pm 3 \mathrm{fg}$ & $760 \pm 87 \mathrm{~d}$ & $572 \pm 87$ e \\
\hline & & 950 & $219 \pm 25 \mathrm{c}$ & $41 \pm 4 \mathrm{~b}$ & $175 \pm 32 \mathrm{a}$ & $16.5 \pm 3.3 \mathrm{c}$ & $15 \pm 2$ cde & $168 \pm 121 b$ & $1767 \pm 121 \mathrm{a}$ \\
\hline \multirow[t]{6}{*}{$\begin{array}{l}\text { San } \\
\text { Andreas }\end{array}$} & $25^{\circ} \mathrm{C}$ & 400 & $114 \pm 24 \mathrm{f}$ & $24 \pm 4 \mathrm{f}$ & $28 \pm 3 \mathrm{~g}$ & $9.8 \pm 1.1 \mathrm{e}$ & $18 \pm 3 \mathrm{~cd}$ & $603 \pm 85 \mathrm{e}$ & $591 \pm 85 \mathrm{e}$ \\
\hline & & 650 & $154 \pm 18 \mathrm{de}$ & $31 \pm 4 \mathrm{de}$ & $66 \pm 8$ ef & $20.1 \pm 2.6 \mathrm{~b}$ & $10 \pm 2$ efg & $532 \pm 65 \mathrm{e}$ & $595 \pm 65$ e \\
\hline & & 950 & $348 \pm 33$ a & $62 \pm 6 \mathrm{a}$ & $128 \pm 18 \mathrm{c}$ & $25.1 \pm 3.3 \mathrm{a}$ & $52 \pm 7 \mathrm{a}$ & $1849 \pm 33 \mathrm{a}$ & $949 \pm 33 \mathrm{c}$ \\
\hline & $30^{\circ} \mathrm{C}$ & 400 & $172 \pm 60 \mathrm{~d}$ & $34 \pm 3 \mathrm{~cd}$ & $48 \pm 5 \mathrm{fg}$ & $20.4 \pm 2.4 \mathrm{~b}$ & $45 \pm 5 b$ & $469 \pm 49 \mathrm{~b}$ & $1407 \pm 49 \mathrm{~b}$ \\
\hline & & 650 & $160 \pm 28 \mathrm{de}$ & $34 \pm 4 \mathrm{c}$ & $57 \pm 4$ ef & $22.6 \pm 3.8 \mathrm{ab}$ & $9.9 \pm 2 \mathrm{def}$ & $626 \pm 25 \mathrm{e}$ & $590 \pm 25 \mathrm{e}$ \\
\hline & & 950 & $231 \pm 26 \mathrm{c}$ & $58 \pm 6 \mathrm{a}$ & $150 \pm 22 \mathrm{~b}$ & $13.9 \pm 1.7 \mathrm{~d}$ & $9.4 \pm 2 \mathrm{fg}$ & $1439 \pm 28 \mathrm{c}$ & $1527 \pm 28 \mathrm{~b}$ \\
\hline \multirow{2}{*}{\multicolumn{3}{|c|}{$\begin{array}{l}\text { Temperature } \times\left[\mathrm{CO}_{2}\right] \\
\text { Temperature } \times\left[\mathrm{CO}_{2}\right] \times \\
\text { Cultivar }\end{array}$}} & * & * & * & * & * & * & * \\
\hline & & & * & $*$ & $*$ & $*$ & $*$ & * & * \\
\hline
\end{tabular}

Values are mean $\pm \operatorname{SD}(\mathrm{n}=12)$, different letters in each column are significantly ( $\mathrm{p} \mathrm{d} 0.05)$ different. 


\section{Table IV}

Table IV. Effect of different temperature and $\left[\mathrm{CO}_{2}\right]$ on other polyphenol compounds in strawberry varieties

$\begin{array}{cccccccc}\text { Cultivar } & \text { Temperature } & {\left[\mathrm{CO}_{2}\right]} & \text { Catechin }^{a} & \begin{array}{c}\text { Ferulic } \\ \text { Acid }^{b}\end{array} & p \text {-Coumaroyl } & p \text {-Coumaric }{ }^{d} & \text { Resveratrol } \\ & & & & & & \\ \text { Albion } & 25{ }^{\circ} \mathrm{C} & 400 & 9 \pm 1.6 \mathrm{f} & 24 \pm 0.4 \mathrm{ef} & 4.4 \pm 0.4 \mathrm{c} & 1.07 \pm 0.03 \mathrm{c} & 23 \pm 1 \mathrm{f} \\ & & 650 & 15 \pm 2.4 \mathrm{ef} & 28 \pm 1 \mathrm{~cd} & 10.4 \pm 0.8 \mathrm{~b} & 1.35 \pm 0.03 \mathrm{c} & 65 \pm 8 \mathrm{~cd} \\ & & 950 & 32 \pm 4.8 \mathrm{~d} & 23 \pm 1 \mathrm{e} & 10.7 \pm 0.3 \mathrm{~b} & 2.86 \pm 0.02 \mathrm{a} & 59 \pm 3 \mathrm{de} \\ & 30{ }^{\circ} \mathrm{C} & 400 & 9 \pm 0.7 \mathrm{f} & 63 \pm 4 \mathrm{~b} & 5.5 \pm 0.8 \mathrm{c} & 3.23 \pm 0.03 \mathrm{a} & 66 \pm 2 \mathrm{~cd} \\ & & 650 & 21 \pm 0.4 \mathrm{e} & 30 \pm 2 \mathrm{~b} & 9.4 \pm 1.9 \mathrm{~b} & 2.98 \pm 0.03 \mathrm{a} & 84 \pm 7 \mathrm{~b} \\ & & 950 & 43 \pm 5.8 \mathrm{c} & 29 \pm 1 \mathrm{~cd} & 14.0 \pm 1.6 \mathrm{a} & 2.39 \pm 0.03 \mathrm{~b} & 113 \pm 5 \mathrm{a} \\ \text { San } & & & & & & & \\ \text { Andreas } & 25{ }^{\circ} \mathrm{C} & 400 & 8 \pm 0.8 \mathrm{f} & 24 \pm 0.4 \mathrm{ef} & 4.4 \pm 0.3 \mathrm{c} & 1.05 \pm 0.02 \mathrm{c} & 23 \pm 2 \mathrm{f} \\ & & 650 & 20 \pm 2.2 \mathrm{e} & 30 \pm 0.9 \mathrm{~cd} & 11.0 \pm 0.9 \mathrm{~b} & 2.15 \pm 0.02 \mathrm{~b} & 71 \pm 6 \mathrm{c} \\ & & 950 & 58 \pm 4.3 \mathrm{a} & 25 \pm 2 \mathrm{f} & 13.9 \pm 0.9 \mathrm{a} & 2.79 \pm 0.02 \mathrm{a} & 58 \pm 5 \mathrm{e} \\ & 30{ }^{\circ} \mathrm{C} & 400 & 8 \pm 0.8 \mathrm{f} & 67 \pm 3 \mathrm{a} & 5.6 \pm 0.8 \mathrm{c} & 2.89 \pm 0.03 \mathrm{a} & 71 \pm 3 \mathrm{c} \\ & & 650 & 30 \pm 4.4 \mathrm{~d} & 31 \pm 2 \mathrm{c} & 10.2 \pm 1.7 \mathrm{~b} & 2.90 \pm 0.03 \mathrm{a} & 82 \pm 6 \mathrm{~b} \\ & & 950 & 50 \pm 6.0 \mathrm{~b} & 28 \pm 0.4 \mathrm{~cd} & 15.4 \pm 0.7 \mathrm{a} & 2.96 \pm 0.08 \mathrm{a} & 68 \pm 2 \mathrm{c}\end{array}$

Temperature $\times\left[\mathrm{CO}_{2}\right]$

Temperature $\times\left[\mathrm{CO}_{2}\right] \times$ Cultivar

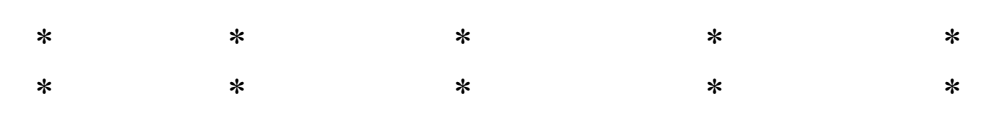

$\boldsymbol{a}, \boldsymbol{b}, \boldsymbol{c} \boldsymbol{d}$ expressed as $\mathrm{mg} / \mathrm{kg} \mathrm{FW},{ }^{e}$ expressed as $\mu \mathrm{g} / \mathrm{kg} \mathrm{FW} .{ }^{*}$ significant $\left(\mathrm{p} d\right.$ 0.05). $\left[\mathrm{CO}_{2}\right]=\mu \mathrm{moL} / \mathrm{moL}$

Values are mean $\pm \operatorname{SD}(n=12)$, different letters in each column are significantly ( $\mathrm{p} \mathrm{d} 0.05)$ different. 


\section{University Library}

\section{- M M I N E R VA A gateway to Melbourne's research publications}

Minerva Access is the Institutional Repository of The University of Melbourne

Author/s:

Balasooriya, HN;Dassanayake, KB;Seneweera, S;Ajlouni, S

Title:

Impact of elevated carbon dioxide and temperature on strawberry polyphenols

Date:

2019-08-15

Citation:

Balasooriya, H. N., Dassanayake, K. B., Seneweera, S. \& Ajlouni, S. (2019). Impact of elevated carbon dioxide and temperature on strawberry polyphenols. JOURNAL OF THE SCIENCE OF FOOD AND AGRICULTURE, 99 (10), pp.4659-4669. https://doi.org/10.1002/ jsfa.9706.

Persistent Link:

http://hdl.handle.net/11343/285773 